\title{
GEOTHERMAL DEVELOPMENT PLAN: NORTHERN ARIZONA
}

\author{
Prepared by \\ The Arizona Geothermal Commercialization Team \\ Don H. White, Ph.D., Principal Investigator \\ Larry A. Goldstone, Project Manager \\ Arizona Geological Survey \\ Open-File Report 80-10
}

1980

\author{
Arizona Geological Survey \\ 416 W. Congress, Suite \#100, Tucson, Arizona 85701 \\ State Contractor: \\ Arizona Solar Energy Commission, James F. Warnock, Jr., Director \\ Frank Mancini, Ph.D., Associate Director \\ 1700 West Washington, Phoenix, Arizona 85007 \\ Work performed under Contract No. DE-FC03-80RA50076 \\ Modification No. A-001 \\ Evaluation of Geothermal Energy in Arizona \\ U.S. Department of Energy \\ San Francisco Office Region IX
}

Subcontract 114-80 with Department of Chemical Engineering

University of Arizona Tucson, Arizona 35721

This report is preliminary and has not been edited

or reviewed for conformity with Arizona Geological Survey standards 



\section{ACKNOWLEDGEMENTS}

The Arizona Geothermal Comercialization Team has been comprised of many Individuals over the past several years. Recognition is extended to the following professors who have contributed to the Team's efforts: John Kessler, Ph.D.; Mike Pasqualetti, Ph.D.; and David Wolf, Ph.D.

Group leaders were Mohamad Chehab, Larry Goldstone, Lanf Malysa and Bill Weibel.

Other contributors include Cherif Ballamane, Ronda Bitterli, Wei-hsin (Alex) Chung, Elizabeth Foster, Jeff Hagen, Akram Hasan, Greta Jensen, Gary Kyle, Timeral Rowe, Edward Seames and John Westover.

The following people were special task contributors: Don Astrom, Greta Jensen, Iftikhar Khan, Doug Linkhart, Lani Malysa, Mobin Qaheri, Xavier Suarez, Charles Tabet and Steve Unguran.

In addition, W. Richard Hahman, Sr., Claudia Stone and Jim Witcher of the Arizona Bureau of Geology and Mineral Technology-Geothermal Group deserve recognition for their contributions and assistance.

Special thanks are extended to Bette Holt for drafting some of the figures and to Peggy Jackson and Lee DeYonghe for their assistance in typing the final manuscript. 
LIST OF FIGURES . . . . . . . . . . . . . . . . . . . ii

LIST OF TABLES . . . . . . . . . . . . . . . . . iv

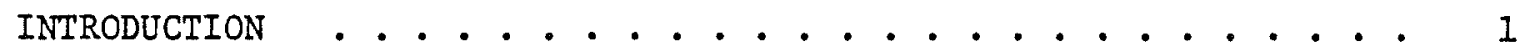

AREA DEVELOPMENT PLANS . . . . . . . . . . . . . . . . 2

GEOTHERMAL RESOURCES . . . . . . . . . . . . . . . 2

ECONOMY •. . . . . . . . . . . . . . . . . . . . .

Population ......................... 4

Growth ........................... . . . . 4

Industry and Employment . . . . . . . . . . . . . 6

Income . . . . . . . . . . . . . . . . . . . 6

Other Economic Indicators . . . . . . . . . . . . . 10

LAND OWNERSHIP . . . . . . . . . . . . . . . . . 11

ENERGY USE .......................... 18

VATER .......................... 22

DISTRICT HEATING . . . . . . . . . . . . . . . 30

Alpine . . . . . . . . . . . . . . . . . . . 30

Springerville . . . . . . . . . . . . . . . . 34

MATCHING GEOTHERMAL RESOURCES TO POTENTIAL USERS . . . . . . . 37

Ready-Mix Concrete Industry . . . . . . . . . . . . . 44

Sawnills Industry . . . . . . . . . . . . . . . 44

APPENDIX A . . . . . . . . . . . . . . . . 46

BIBLIOGRAPHY . . . . . . . . . . . . . . . 48 
LIST OF FIGURES

Figure

Page

1 Area Development Plans for Arizona

2 Population Projections for the Northern Arizona Countles to 2020

3 Major Employment Sector Projections for the Northern Counties 7

4 Other Employment Sector Projections for the Northern Counties 8

5 Projections of Personal Per Capita Income for the Northern Counties (1972 Dollars)

6 General Land Ownership Map for Apache County

7 General Land Ownership Map for Coconino County

8 General Land Ownership Map for Gila County

9 General Land Ownership Map for Mohave County

10 General Land Ownership Map for Navajo County

11 General Land Ownership Map for Yavapai County

12 Estimated Natural Gas Sales by Month in 1979 for Prescott (Yavapai County)

13 Estimated Natural Gas Sales by Month in 1979 for Kingman (Mohave County)

14 Estimated Natural Gas Sales by Month in 1979 for Flagstaff (Coconino County)

15 Projected Alternatives for Water Use in Gila County 23

16 Projected Alternatives for Water Use in Navajo County 24

17 Projected Alternatives for Water Use in Apache County 25

18 Projected Alternatives for Water Use In Yavapai County 26

19 Projected Alternatives for Water Use in Coconino County 27

20 Projected Alternatives for Water Use in Mohave County 28

21 Projected Geothermal Heat on Line Under Private Development 38 
LIST OF FIGURES continued

Figure

Page

22 Projected Geothermal Heat on Line Under City Development

39

23 Projected Geothermal Heat on Line Under Private Development for the Residential, Comercial and Industrial Sectors

24 Projected Goethermal Heat On Line Under City Development for the Residential, Commercial and Industrial Sectors 
INTRODUCTION

Alternative sources of energy will have to be developed as the availability of traditional energy resources continues to diminish. Arizona is supplied with geothermal reserves which could potentially supplement the existing energy supplies. Consequently, planning efforts have concentrated on estimating the potential of geothermal energy utilization in Arizona and in providing information necessary for its prospective commercialization.

Geothermal commercialization plans were prepared for seven distinct intrastate subdivisions. The geothermal resource prospect and the potential geothermal uses for each area are discussed in separate Area Development Plans (ADPS). The major objective of the ADP is to provide information for the prospective development and commercialization of geothermal energy in the specified area. Attempts are made to match the aṽailable geothermal resources to potential residential, comercial, industrial and agricultural users.

Much of the northern counties (Apache, Coconino, Gila, Mohave, Navajo and Yavapai) is located in the Colorado Plateau province, a region of low geothermal potential. Two areas that do show some potential are the Flagstaff - San Francisco Peaks area and the Springerville area. Flagstaff is rapidly becoming the manufacturing center of Arizona and will have many opportunities to use geothermal energy to satisfy part of its increasing need for energy. Using a computer simulation model, projections of geothemal energy on line as a function of time are made for both private and city-owned utility development of a resource. 


\section{AREA DEVEIOPMENT PLANS}

Arizona has been divided into seven distinct single or multicounty subdivisions for which Area Development Plans (ADPs) for geothermal commercialization have been developed, A map of Arizona presented in Figure 1. shows these areas which are numbered in order of planning priority.

This ADP is concerned with the northern counties. Both metric and English units are provided in the text. However, only metric units appear in the tables and figures. For convenience, some common conversion factors are listed in Table 1 . In this report, one million $B t u=M B t u$.

TABLE 1: SOME COMMON CONVERSION FACTORS

\begin{tabular}{|c|c|c|}
\hline To Convert: & Multiply By: & To Obtain: \\
\hline meters & 3.281 & feet \\
\hline kilometers & 0.6214 & miles \\
\hline cubic kilometers & 0.2399 & cubic miles \\
\hline Iiters & 0.2642 & gallons \\
\hline
\end{tabular}

GEOTHERMAL RESOURCES

Much of the northern counties is located in the Colorado Plateau province, a region characterized by low heat flow and little geothermal potential. The Flagstaff - San Francisco Peaks and the Springerville areas, however, do exhibit some geothermal potential. Geologically young volcanism has occurred in the San Francisco Peaks area, and U.S. Geological Survey studies in the San Francisco Peaks volcanic field suggest that there may be significant residual volcanic heat at depth. 


\section{Prortiries}

I) Maricopa

II) PIma

III) Graham/Greenlee

IV) PInal

V) Tua

VI) Cochise/Santa Cruz

VII) Northern Countes $(1,3,4,8,9,13)$

\section{County Names}

1. Apache

2. Cochise

3. Coconino

4. G11a

5. Graham

6. Greenlee

7. Marlcopa

8. Mohave

9.- Navajo

10. Pima

11. Pinal

12. Sasta Cruz

13. Yavapa1

14. Yuma

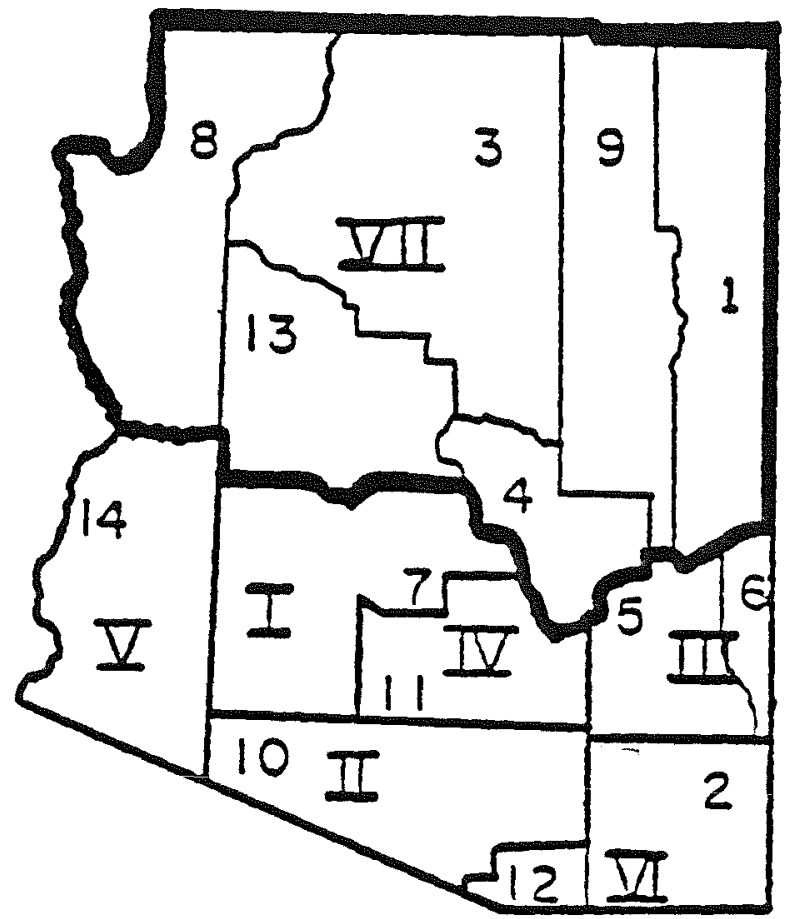

Figure 1: Area Development Plans for Arizona. 
Abnomally high heat flow occurs in the Springerville area, an area located in northeastern Arizona (Apache County) where both geologically young and extinct volcanoes are observed. There is one hot spring in Apache County that discharges water having a temperature of $21.7^{\circ} \mathrm{C}\left(71.1^{\circ} \mathrm{F}\right)$ : Sixty wells located in the county ranging from $200 \mathrm{~m}(660 \mathrm{ft}$ ) to $400 \mathrm{~m}$ (1310 ft) in depth produce water ranging in temperature from $20^{\circ} \mathrm{C}\left(68^{\circ} \mathrm{F}\right)$ to $27^{\circ} \mathrm{C}\left(81^{\circ} \mathrm{F}\right)$.

Further studies are being conducted by the Arizona Bureau of Geology and Mineral Technology to identify additional geothermal resources. Results of these studies will be available next year.

ECONOMY

\section{Population}

The 1980 population of the northern Arizona counties was 355,657 people. The combined land area of the counties is 65,709 square miles which results in a population density of 5.4 persons per square mile. The ethnic breakdown of the population is 55 percent white, 28 percent Indian, 11 percent Hispanic and 1 percent black.

\section{Growth}

Since 1970 the northern counties have experienced an annual population growth rate of 5.8 percent. Table 2 shows the annual population growth for each of the counties from 1970 to 1978 .

Population projections for the combined counties indicated in Figure 2 show steady growth for the next forty years.

The largest city in northern Arizona is Flagstaff. This city is rapidly becoming the manufacturing center of northern Arizona due to its access to two main interstates. 


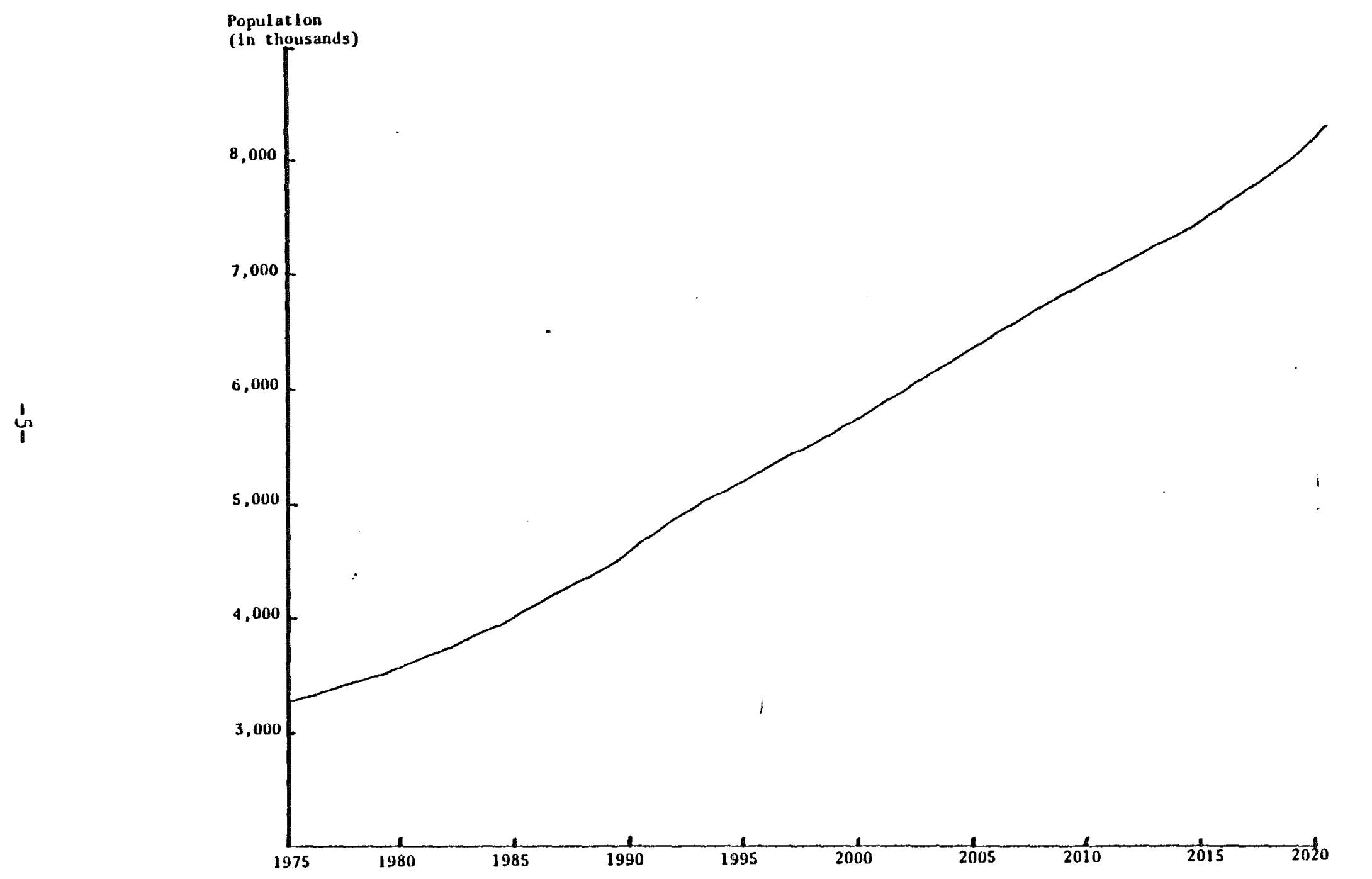

Flgure 2: Population Projections for the Northern Arizona Counties to 2020 .

Source: Technical Advisory Committee (DES) 
TABLE 2: ANNUAL POPULATION GROWTH RATES FOR THE NORTHERN COUNTIES, $1970-1978$

County

Mohave

Yavapai

Apache

Coconino

Navajo

Gila
Annual Growth Rate

$9.8 \%$

$7.7 \%$

$6.5 \%$

$4.1 \%$

$4.0 \%$

$2.5 \%$

\section{Industry and Employment}

Figures 3 and 4 show current and projected employment levels for the various sectors in the northern counties. Presently, the largest employment sectors are the trade and service sectors. By the year 2000, the trade and service sectors are projected to increase 77 percent and 79 percent, respectively; manufacturing is projected to increase 67 percent and the mining and utility sectors are both expected to grow 71 percent. Employment in agriculture is expected to decrease 17 percent.

The Department of Economic Security estimates that total employment in the northern counties will rise 1.8 percent annually to the year 2000 . Income

In addition, several other economic indicators show positive growth in northern Arizona. Figure 5 presents projections of personal per capita income for the northern counties to 2000. Annual growth rates are shown in Table 3.

These income figures represent a slower rate of growth than is common in the more populous Maricopa and Pima counties. Also the types of employment found in these two counties tend to have a lower wage scale than the more industrialized counties. 


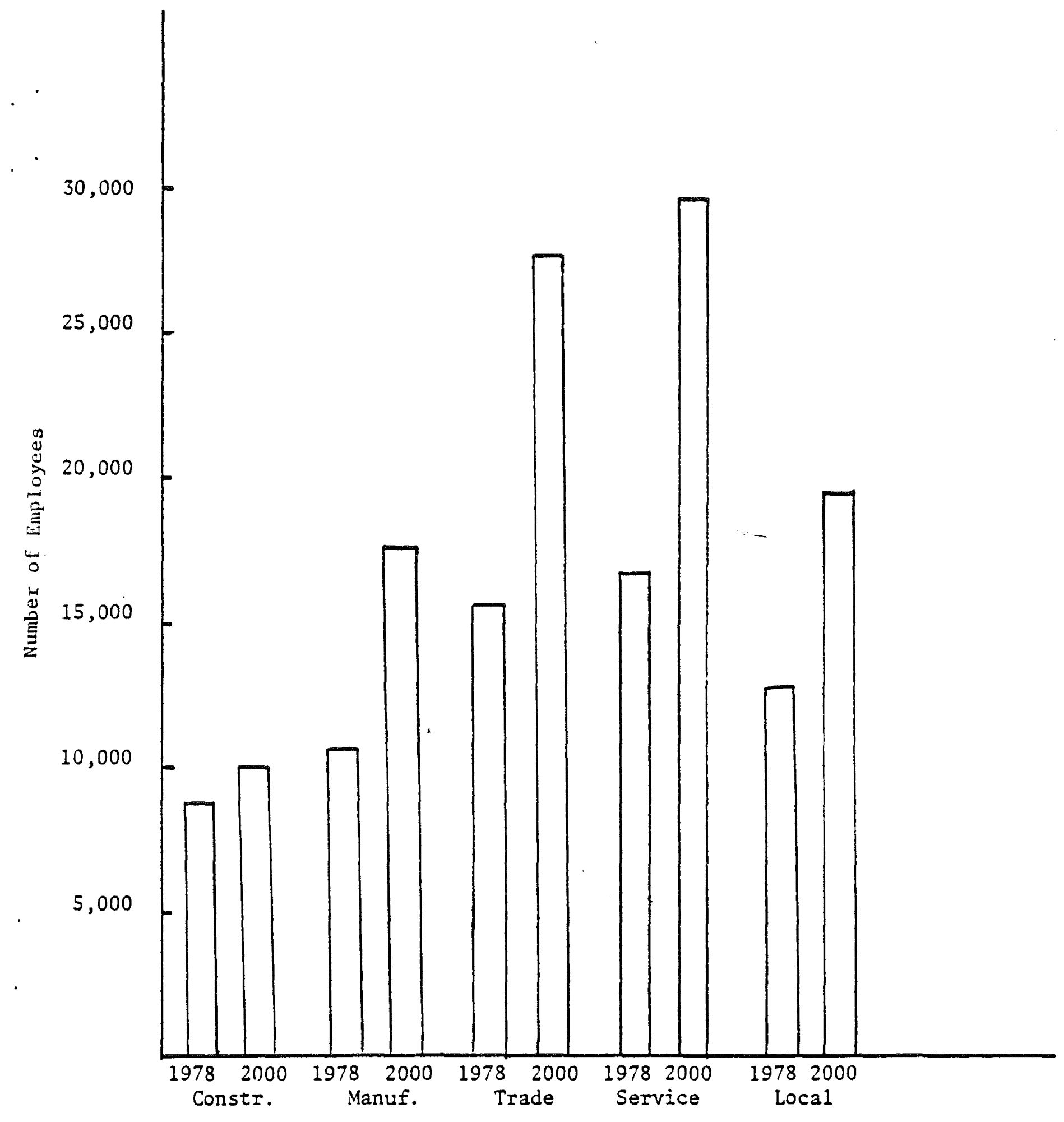

Figure 3: Major Employment Sector Projections for the Northern Counties. Source: Department of Economic Security 


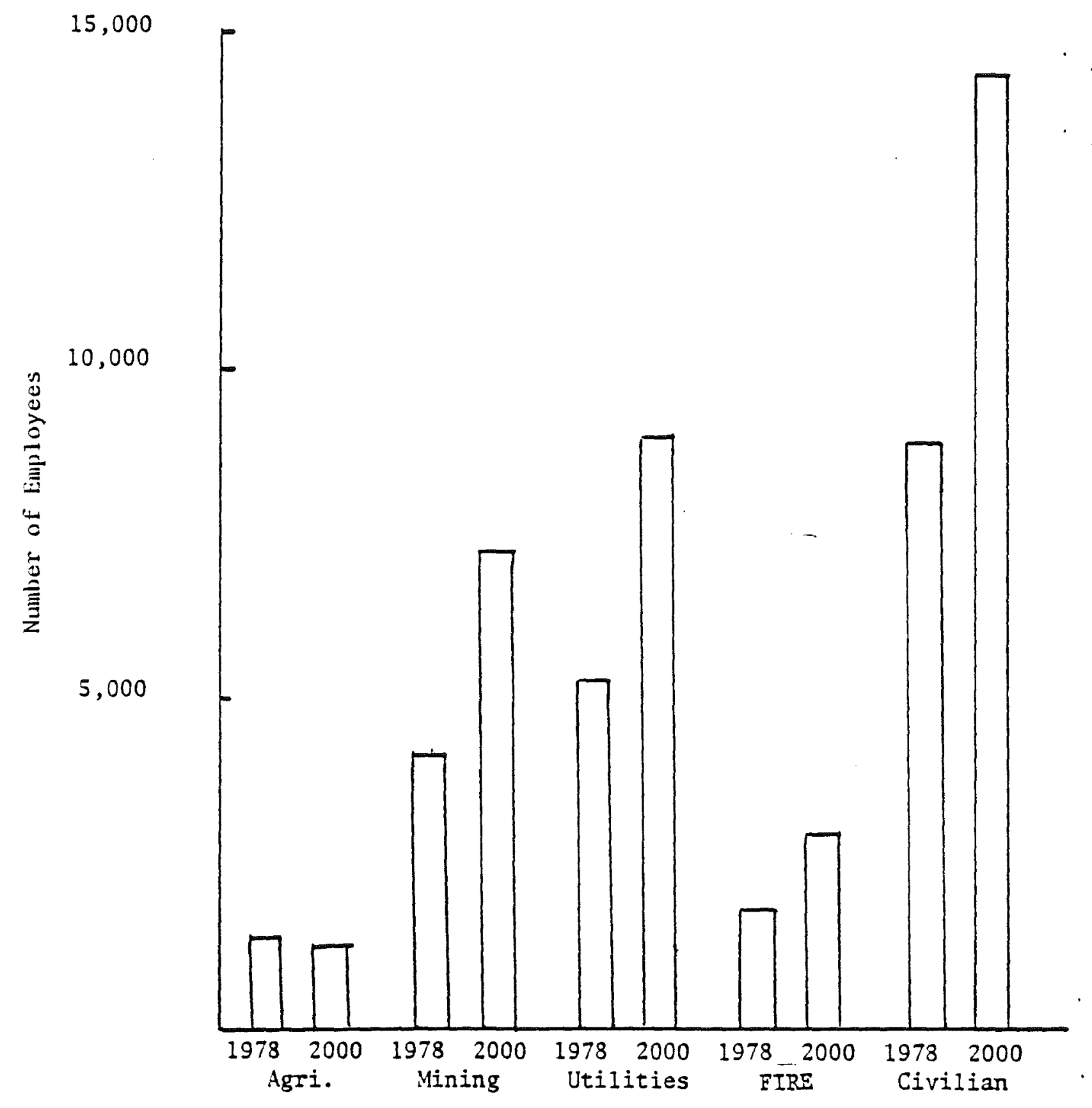

Figure 4: Other Employment Sector Projections for the Northern Counties. Source: Department of Economic Security 


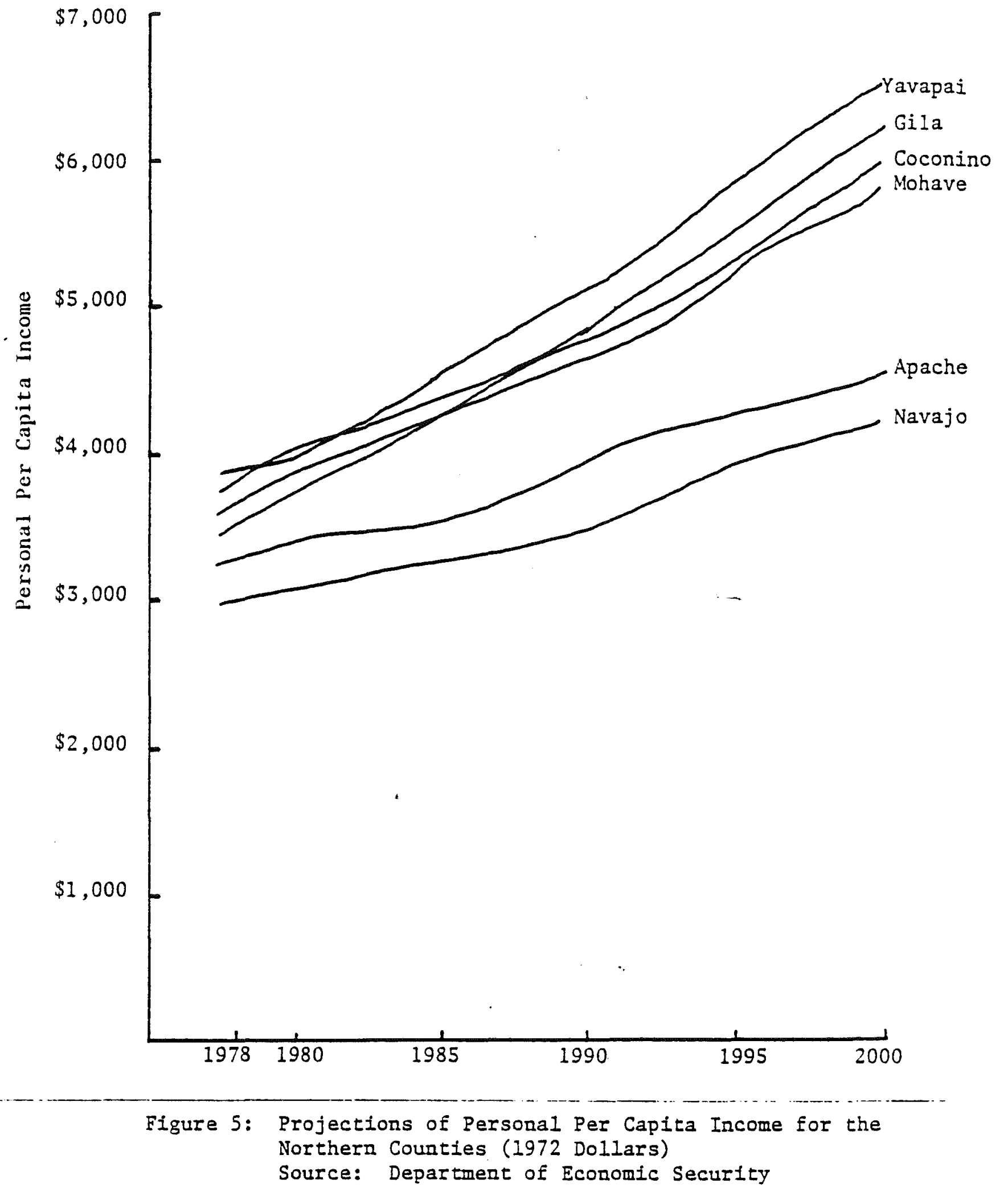


TABLE 3:- PROJECTIONS OF PERSONAL PER CAPITA INCOME GROWTH TO 2000

\begin{tabular}{lcc}
\hline County & $\begin{array}{c}\text { \% Annual Personal } \\
\text { Income Growth }\end{array}$ & $\begin{array}{c}\text { Annual Per Capita } \\
\text { Income Growth }\end{array}$ \\
\cline { 2 - 3 } Apache & 3.6 & 1.6 \\
Coconino & 5.5 & 2.1 \\
Gila & 4.4 & 2.7 \\
Mohave & 4.6 & 2.2 \\
Navajo & 4.2 & 1.6 \\
Yavapai & 4.5 & 2.4 \\
\hline
\end{tabular}

\section{Other Economic Indicators}

Between 1968 and 1978 the value of retail sales steadily increased in both counties. Table 4 indicates the percentage increase in retail sales and bank deposits over the ten-year period.

TABLE 4: RETAIL SALES IN THE NORTHERN COUNTIES

\begin{tabular}{lcc}
\hline County & $\begin{array}{c}\text { \% Increase in } \\
\text { Retail Sales } \\
1968-1978\end{array}$ & $\begin{array}{c}\% \text { Increase in } \\
\text { Bank Deposits }\end{array}$ \\
\cline { 2 - 3 } Apache & 242.1 & $\frac{1968-1978}{231.5}$ \\
Coconino & 231.4 & 239.3 \\
Gila & 195.7 & 152.1 \\
Mohave & 363.4 & 413.0 \\
Navajo & 360.1 & 270.9 \\
Yavapai & 300.2 & 212.2 \\
\hline
\end{tabular}

The sparse population of the northern counties and the lack of an industrial base have resulted in few potential developers of geothermal energy. However, increases in the major economic indicators suggest that the historically slow growth of the northern counties is changing. With population 
growth and the encouragement of light industry, the opportunities to use geothermal energy will also increase.

LAND QWNERSHIP

Figures $6,7,8,9,10$ and 11 show general land ownerships maps for Apache, Coconino, Gila, Mohave, Navajo and Yavapai counties. Table 5 gives acreage breakdowns for each ownership class.

TABLE 5: BREAKDOWN OF LAND OWNERSHIP

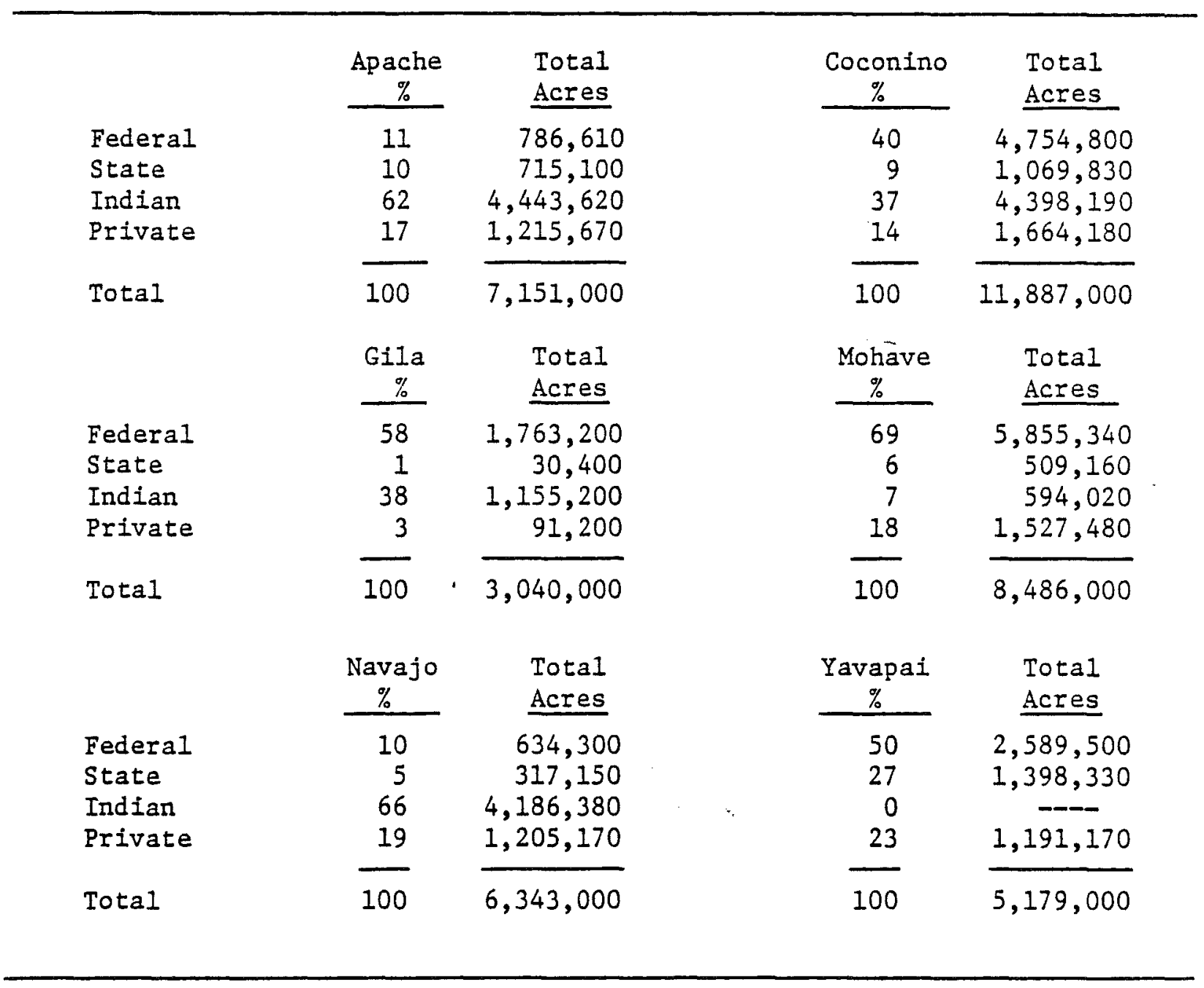




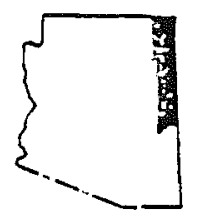

LEGENO

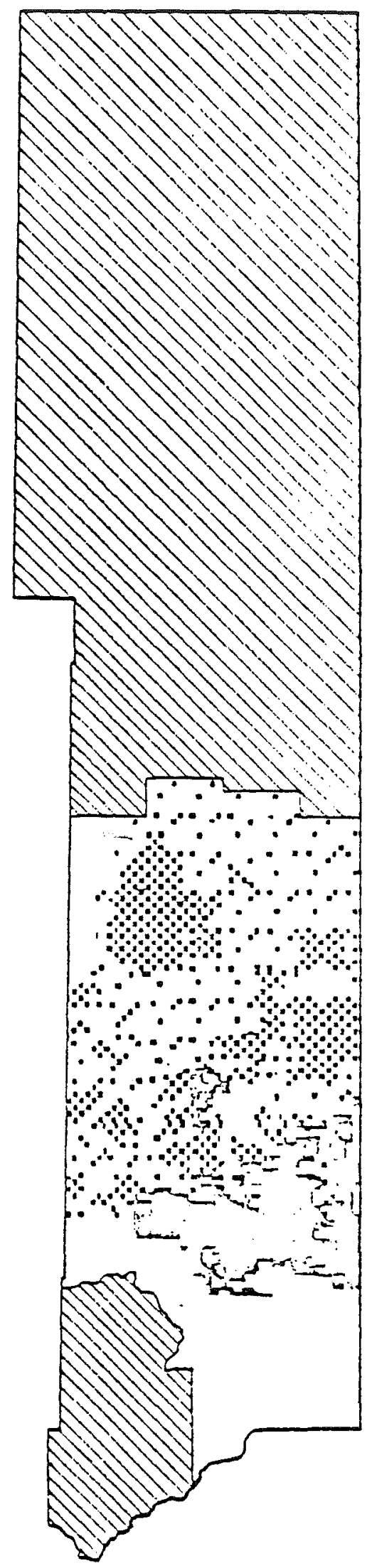

state

DiNOIAN

FEOERAL
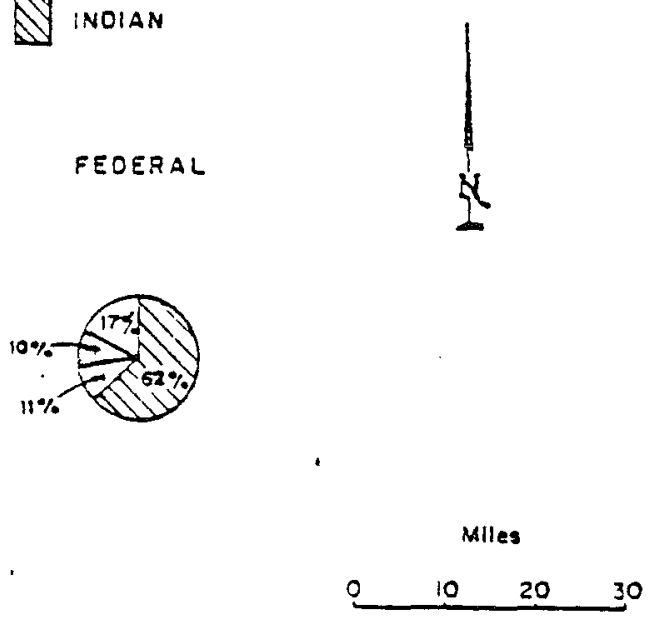

Figure 6: General Land Ownership Map for Apache County. Source: Arizona Water Commission (1977) 


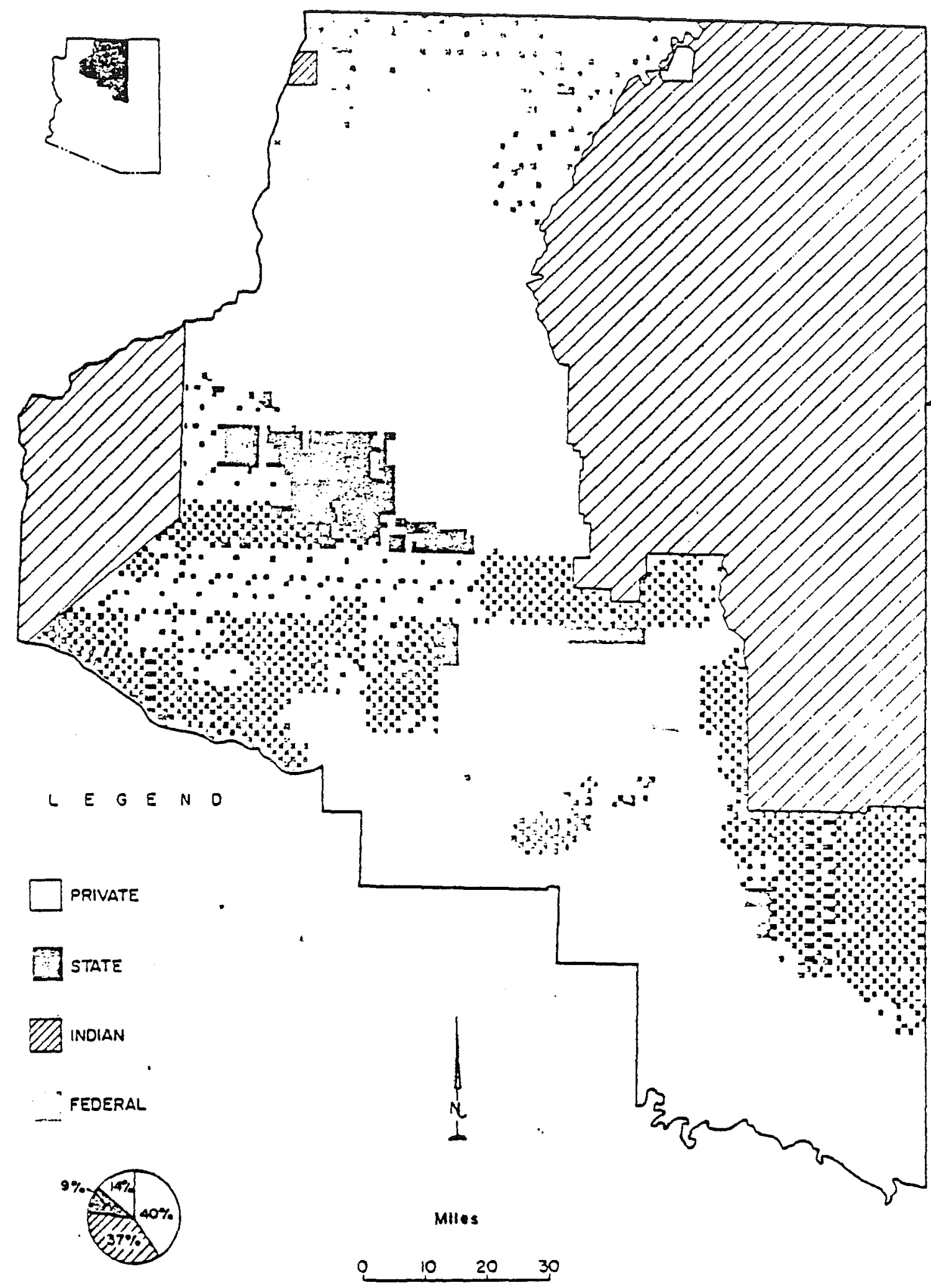

Eigure 7: General Land Ownership Map for Coconino County. Source: Arizona Water Comission (1977) 

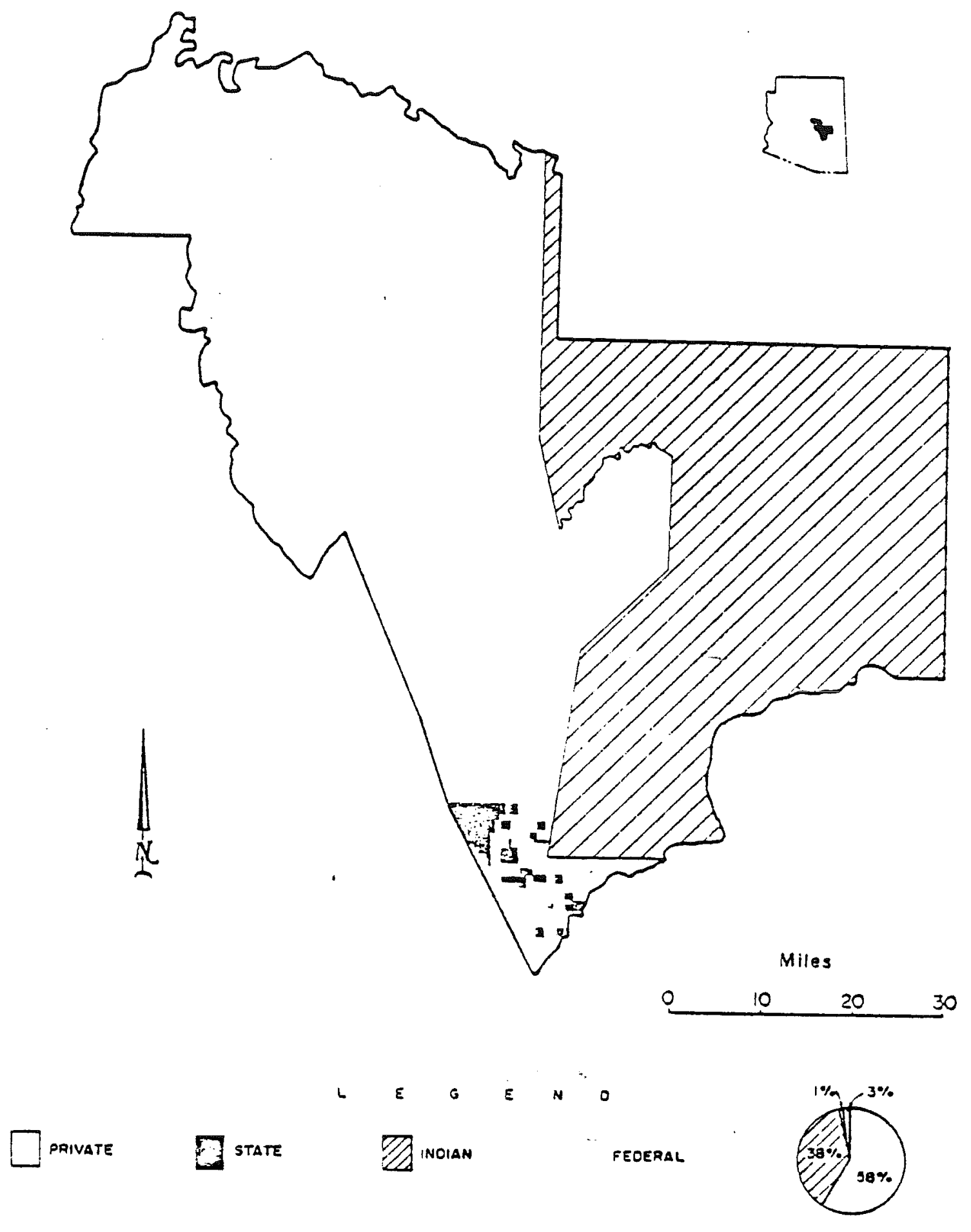

\footnotetext{
Figure 8: General Land Ownership Map for Gila County. Source: Arizona Water Commission (1977)
} 

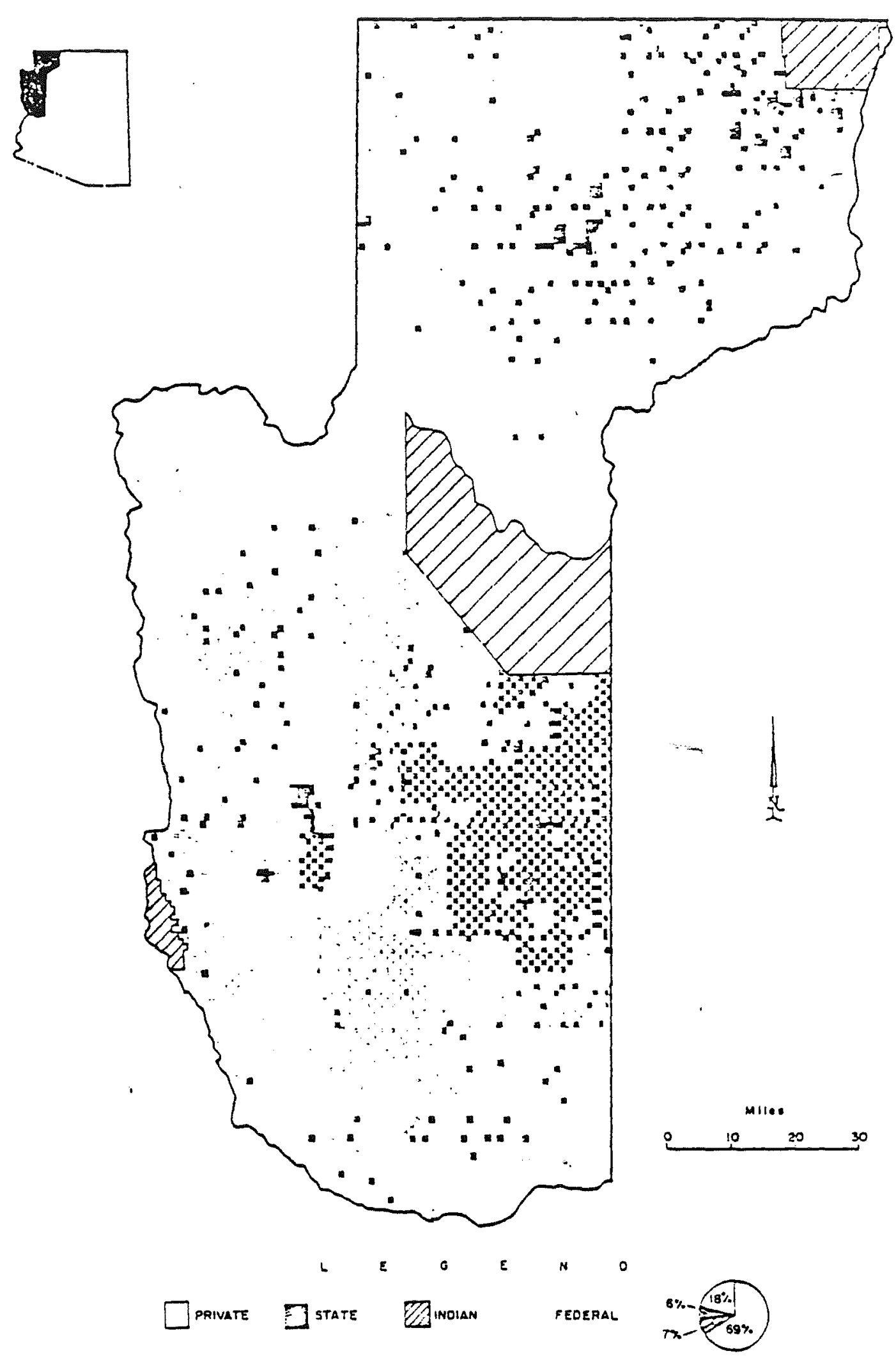

Figure 9: General Land Ownership Map for Mohave County. Source: Arizona Water Comission (1977) 

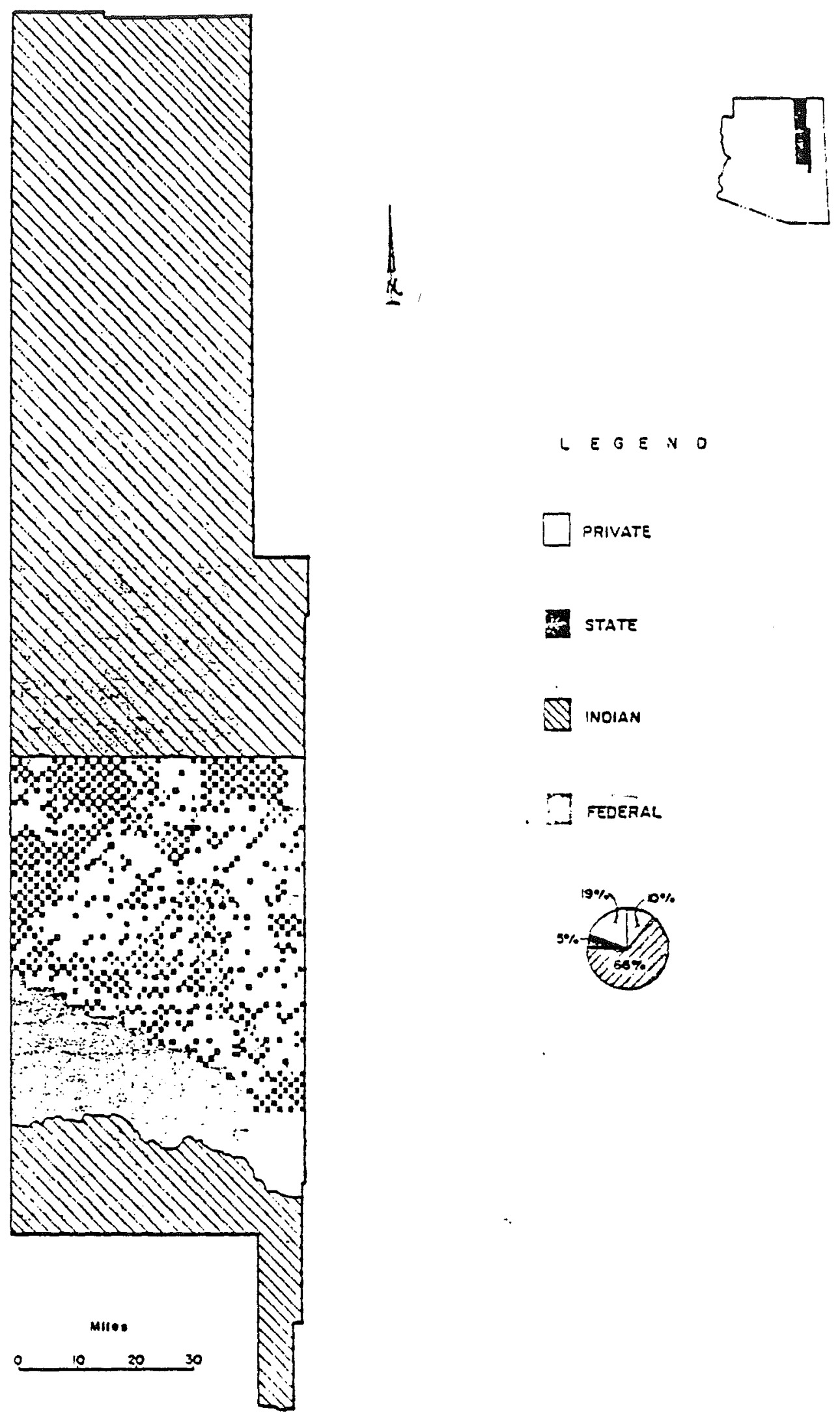

$$
\text { L }
$$

LE G E N D

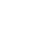



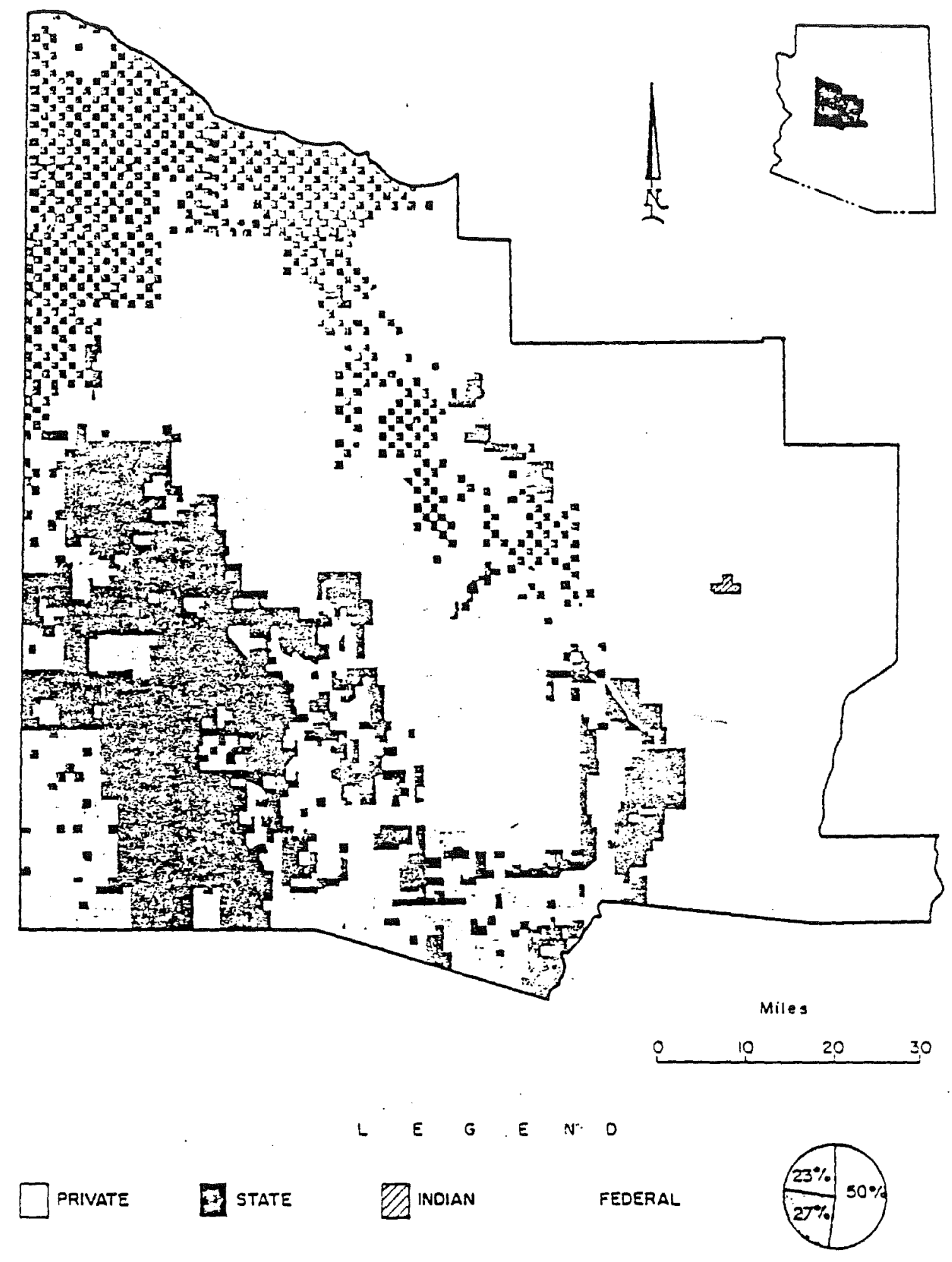

Figure 11: General Land Ownership Map for Yavapai County. Source: Arizona Water Commission (1977) 
ENERGY USE

The largest electric utility company serving northern Arizona is Arizona Public Service Company. Other electric utility companies include Navopache Electric Cooperative which serves both Navajo and Apache counties and Mohave Electric Cooperative, Inc., which serves Mohave County.

Southern Union Gas provides natural gas to Prescott, Kingman and Flagstaff. Natural gas sales for the residential, commercial, public authority and industrial user classes are presented in Figures 12, 13 and 14 for Prescott, Kingman and Flagstaff, respectively. Residential users are clearly the largest consumers of natural gas in the winter months due to the use of natural gas for heating. Demand for natural gas drops off rapidly in the summer months and is at its lowest in August. With one exception, this general pattern of high demand for natural gas in the winter months and decreasing demand in the summer months is consistent for the other user classes as well. Unlike the other user classes, the industrial class of Kingman, consisting primarily of the copper mine northwest of the town, uses more matural gas during the sumer in generating electricity.

For comparative purposes, Table 6 shows the average natural gas consumption per facility for the residential, commercial and industrial user classes of three towns in the northern counties and of the southern counties as a whole. The figures show that the northern counties consume significantly more natural gas than do the southern counties. The disparity can be attributed to the severity of the winters in the northern counties, causing more natural gas to be consumed by the northern counties for heating purposes. 
Sales in MCF

(in thousands)

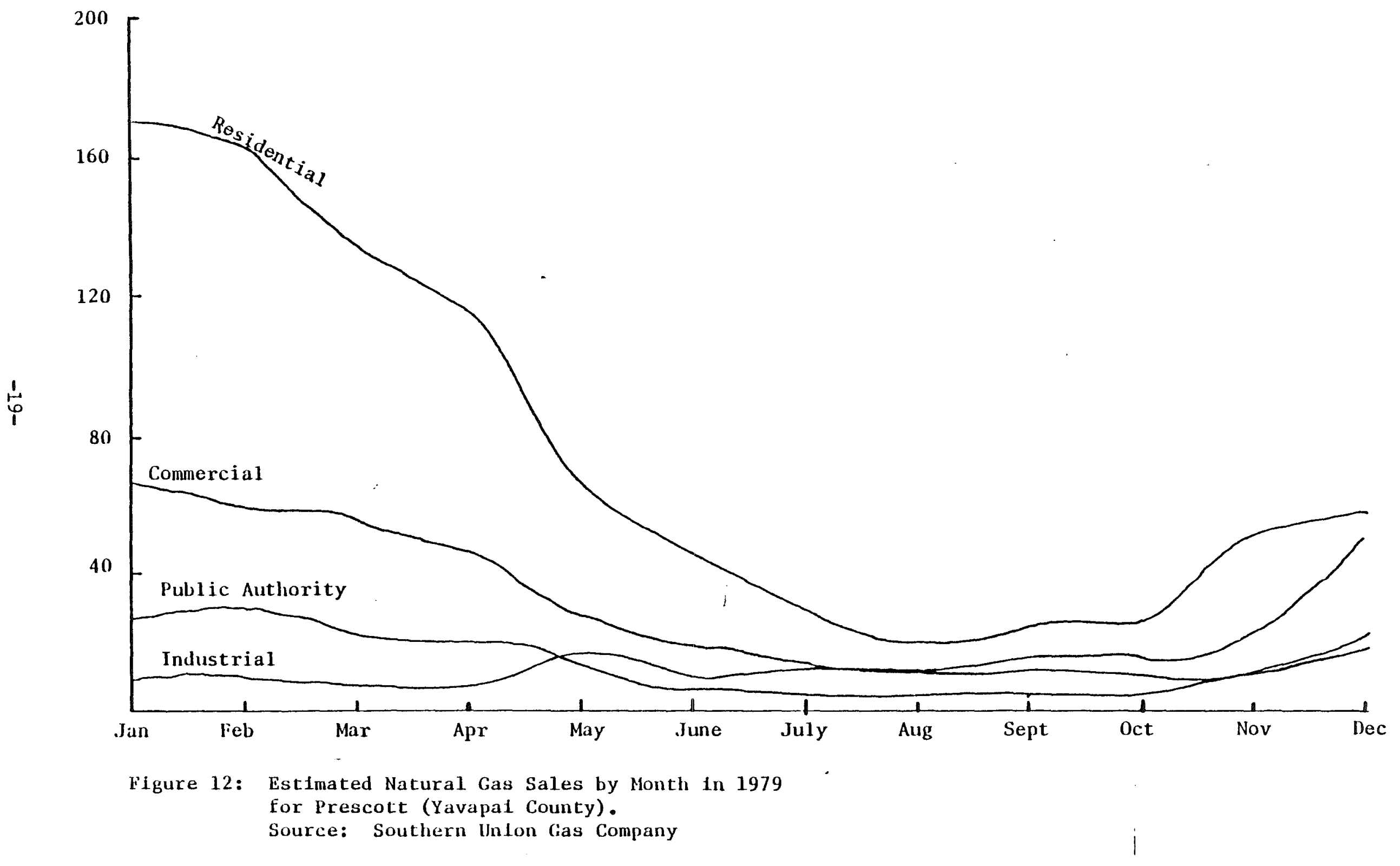


Sales in MCF

(in thousands)

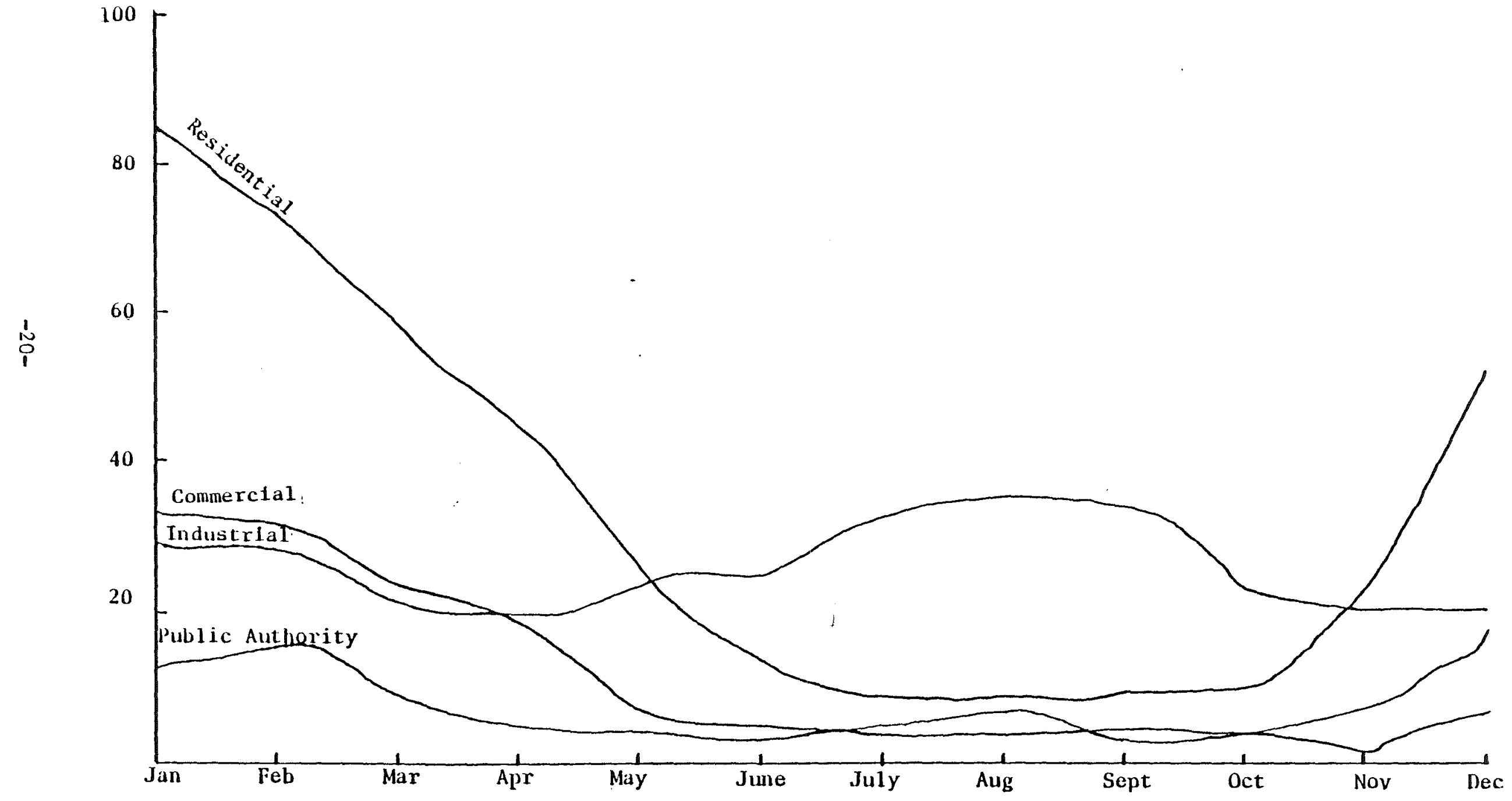

Figure 13: Estimated Natural Gas Sales by Month in 1979 : for Kingman (Mohave County). Source: Southern Unton Gas Company 
Sales in MCF

(in thousands)

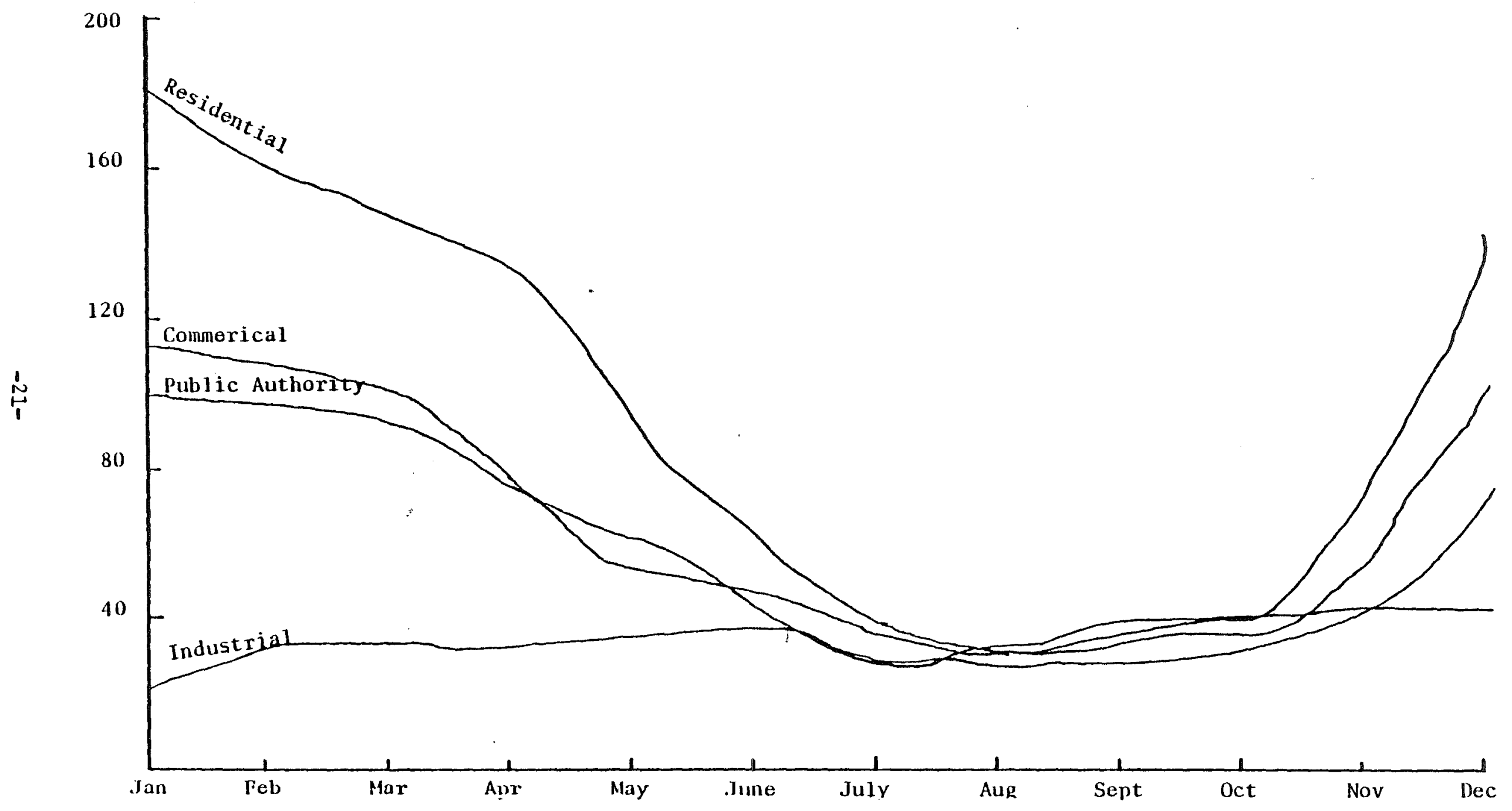

Pigure 14: Estimated Natural Gas Sales by Month in 1979 for Flagstaff (Coconino County). Source: Southern Unton Gas Company 
TABLE 6: COMPARISON OF AVERAGE CONSUMPTION OF NATURAL GAS PER FACILITY BY USER CLASS, 1979

Northern Counties

Flagstaff

Kingman

Prescott

Southern Counties

Southern Counties

Source: Southern Union Gas Corporation Southwest Gas Corporation

\begin{tabular}{|c|c|c|c|}
\hline \multicolumn{2}{|c|}{ Residential } & Commercial & Industrial \\
\hline 134.0 & $\mathrm{MCF}$ & 758.26 & 42416.7 \\
\hline 89.0 & $\mathrm{MCF}$ & 407.45 & 87557.25 \\
\hline 106.3 & $M C F$ & 442.25 & 17555.0 \\
\hline
\end{tabular}

\section{Residential}

62.9 MCF

Commercial

Industrial

467.7

13786,8

WATER

Figures 15 through 20 present alternative futures for water use for the northern counties. The three alternatives take into account a variety of factors such as population growth, industrial development and consumer lifestyles that will have an effect on the future level of water use. In general, urban water depletions are expected to be even greater than what would be expected due to the projected population increases alone. In Apache, Coconino and Navajo counties, the current per capita rate of use is much lower than the remainder of the state. These rates are expected to show small increases.

Because of the scattered nature of most urban water use in northern Arizona, the reuse of water is limited. Therefore, depletions for urban use represent a larger portion of withdrawals for the northern counties than for other parts of Arizona. 


\section{PROJECTED ALTERNATIVE WATER DEPLETIONS AND DEPENDABLE SUPPLY}

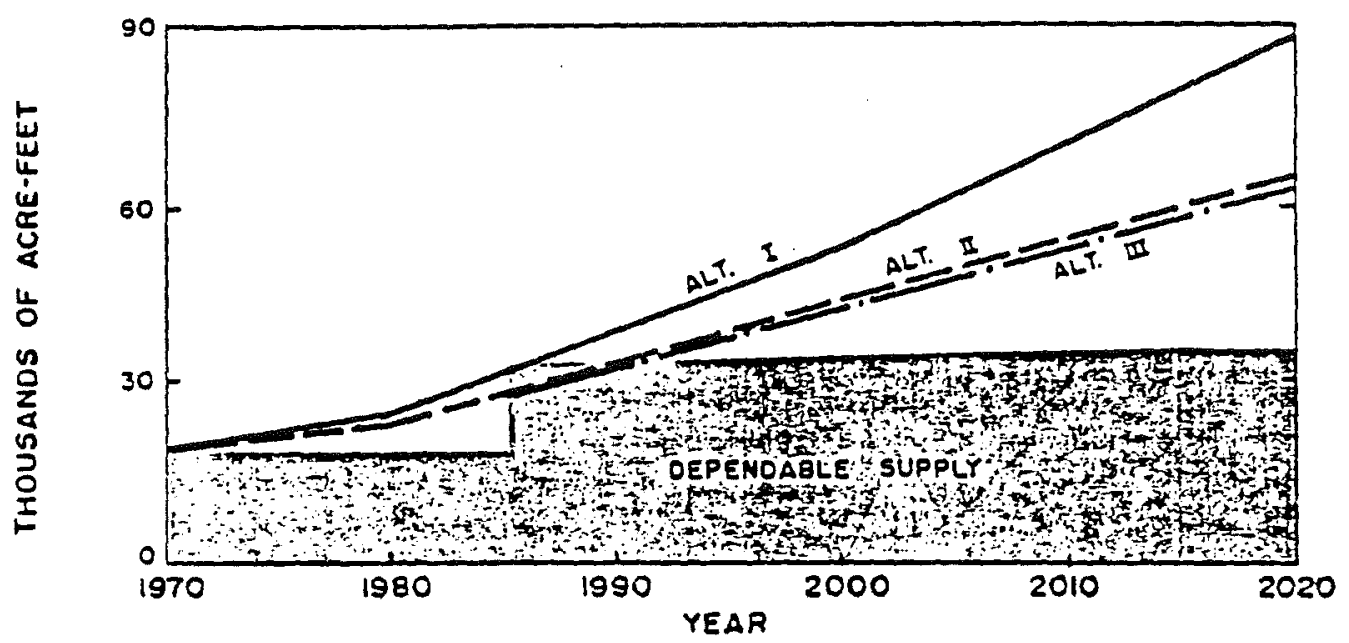

\section{ALTERNATIVE FUTURES SUMMARY}

\begin{tabular}{|c|c|c|c|c|c|c|c|}
\hline \multirow{3}{*}{$\begin{array}{c}\text { ITEM } \\
\text { (Ouentitios in Thovesnds) }\end{array}$} & \multirow[b]{3}{*}{1970} & \multicolumn{3}{|c|}{ ALTEANATIVE } & \multicolumn{3}{|c|}{ FUTURES } \\
\hline & & \multicolumn{2}{|c|}{1} & \multicolumn{2}{|c|}{ II } & \multicolumn{2}{|c|}{ III } \\
\hline & & 1990 & 2020 & 1990 & 2020 & 1990 & 2020 \\
\hline POPULATION & · 29.3 & 53.9 & 65.2 & 40.5 & 56.4 & 40.5 & 56.4 \\
\hline HARVESTED ACRES & 1.0 & 1.2 & 1.3 & 1.0 & 1.0 & 0.8 & 0 \\
\hline UABAN OEPLETIONS AF/YR & 2.9 & 3.8 & 4.9 & 2.9 & 4.2 & 2.9 & 42 \\
\hline STEAM ELECTRIC DEPLETIONS AF/YR & 0 & 0 & 0 & 0 & 0 & 0 & 0 \\
\hline MINERAL DEPLETIONS AF/YA & 140 & 330 & 82.0 & 29.0 & 60.0 & 29.0 & 60.0 \\
\hline AGRICULTURAL DEPL. AF/YA & 2.0 & 2.3 & 2.8 & 2.0 & 2.0 & 1.6 & 0 \\
\hline TOTAL WATEA DEPL. AF/YA & 19 & 39 & 89 & 34 & 66 & 33 & 64 \\
\hline OEPENDABLE WATER AF/YR & 19 & 34 & 37 & \&. 34 & 37 & 34 & 37 \\
\hline SURPLUS SUPPLY (De1.) & 0 & (5) & (52) & 0 & (29) & 1 & (27) \\
\hline
\end{tabular}

Figure 15: Projected Alternatives for Water Use in Gila County. Source: Arizona Water Commission (1977) 


\section{PROJECTED ALTERNATIVE WATER DEPLETIONS}

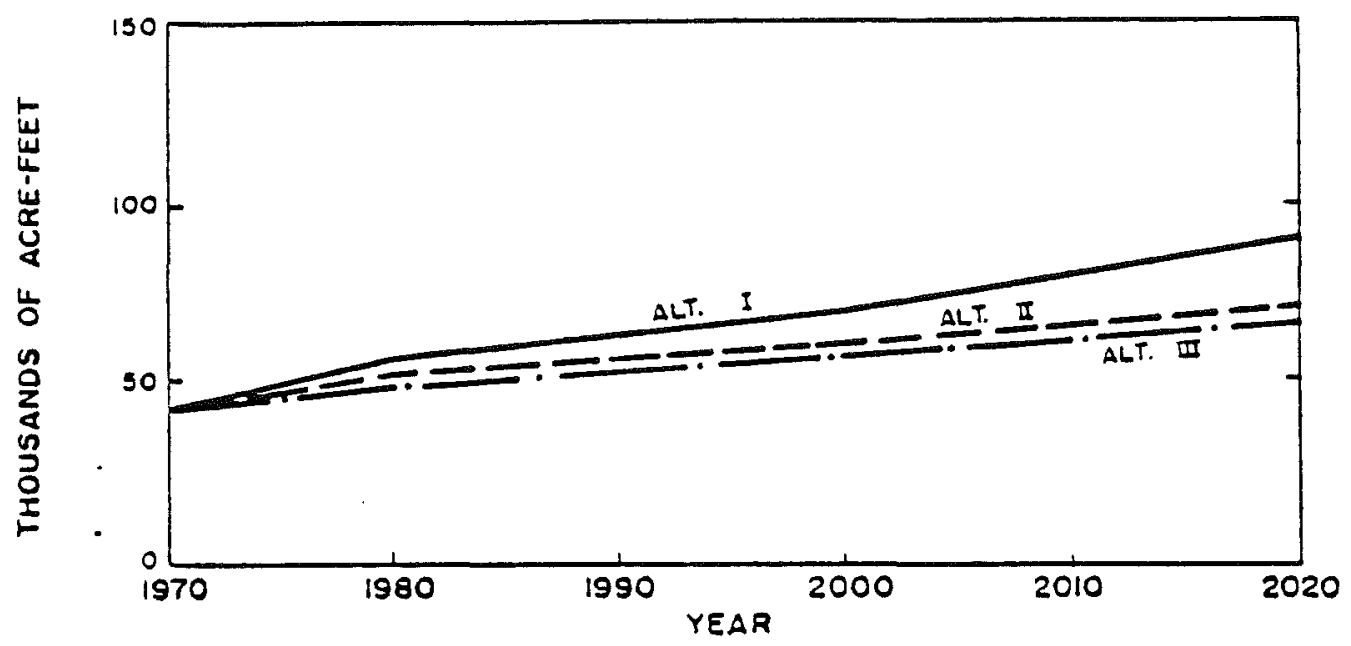

NOTE. Oependable supdy can de developed lo salisty depletions in ail limeliamea

\section{ALTERNATIVE FUTURES SUMMARY}

\begin{tabular}{|c|c|c|c|c|c|c|c|}
\hline \multirow{3}{*}{$\begin{array}{c}\text { ITEM } \\
\text { (Ouentities in Thousende) }\end{array}$} & \multirow[b]{3}{*}{1970} & \multicolumn{3}{|c|}{ ALTERNATIVE } & \multicolumn{3}{|c|}{ FUTURES } \\
\hline & & \multicolumn{2}{|c|}{1} & \multicolumn{2}{|c|}{ II } & \multicolumn{2}{|c|}{ III } \\
\hline & & 1990 & 2020 & 1990 & 2020 & 1990 & 2020 \\
\hline POPULATION & 47.6 & 812 & 1240 & 72.1 & 108.0 & 72.1 & 108.0 \\
\hline MARVESTED ACRES & 13.0 & 145 & 15.0 & 13.0 & 13.0 & 13.0 & 13.0 \\
\hline URBAN OEPLETIONS AF/YR & 15.3 & 16.1 & 19.9 & 15.4 & 18.5 & 15.4 & 18.5 \\
\hline STEAM ELECTRIC DEPLETIONS AFIYA & 3.1 & 13.5 & 36.1 & 11.7 & 22.9 & 11.7 & 22.9 \\
\hline MINEAAL OEPLETIONS AF/YR & 0 & $\$ 0$ & 6.0 & 40 & 5.0 & 40 & 6.0 \\
\hline AGAICULTURAL DEPL. AFIYR & 26.0 & 28.9 & 30.0 & 26.0 & 25.0 & 26.0 & 26.0 \\
\hline TOTAL WATER DEPL. AF/YR & 44 & 62 & 92 & 57 & 73 & 57 & 73 \\
\hline DEPENDABLE WATER AF/YA' & $\$ 4$ & 62 & 92 & 57 & 73 & 57 & 73 \\
\hline SURPLUS SUPPLY (DEI.) & 0 & 0 & 0 & 0 & 0 & 0 & 0 \\
\hline
\end{tabular}

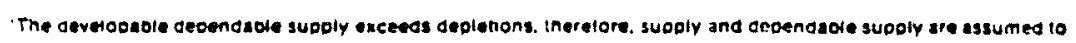
be in ostane.

Deficiencies may exisl in localized areas.

Figure 16: Projected Alternatives for Water Use in Navajo County. Source: Arizona Water Commission (1977) 


\section{PROJECTED ALTERNATIVE WATER DEPLETIONS}

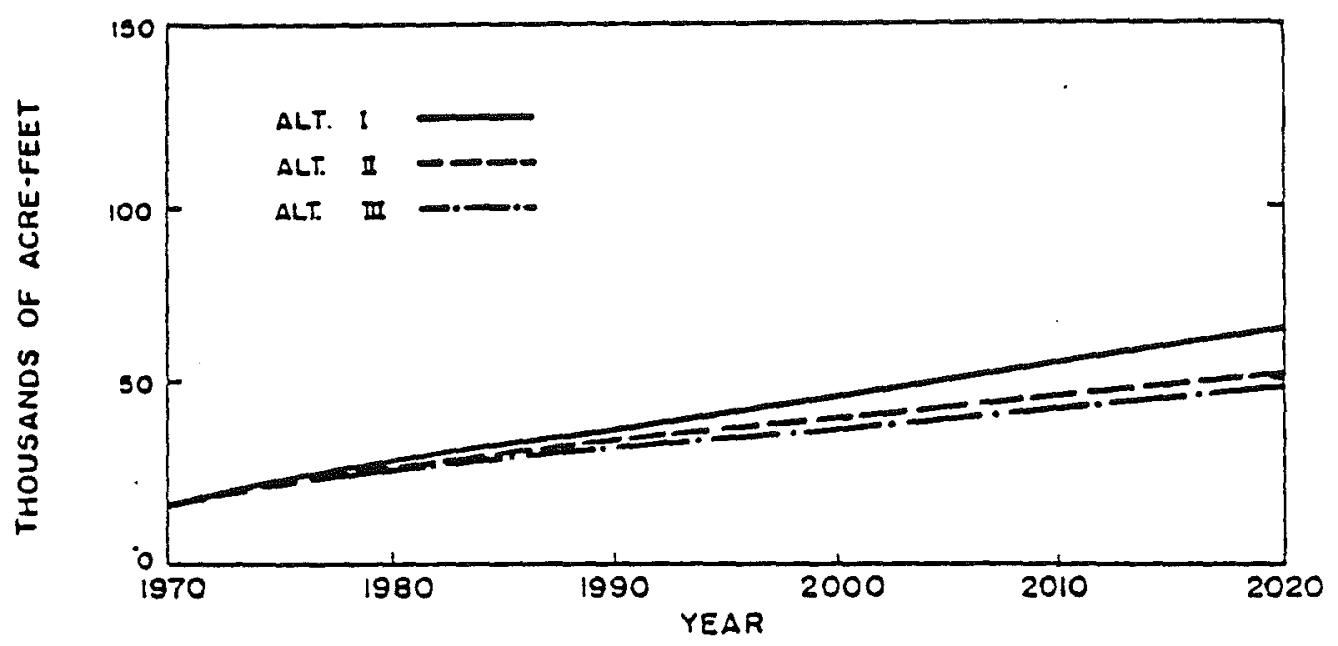

NOTE: Oepencadie supDiy can de developed to sallsiy deptotions in all tumelismes.

\section{ALTERNATIVE FUTURES SUMMARY}

\begin{tabular}{|c|c|c|c|c|c|c|c|}
\hline \multirow{3}{*}{$\begin{array}{c}\text { ITEN } \\
\text { (Ouentites in Thousends) }\end{array}$} & \multirow[b]{3}{*}{1970} & \multicolumn{3}{|c|}{ ALTERNATIVE } & \multicolumn{3}{|c|}{ FUTURES } \\
\hline & & \multicolumn{2}{|c|}{1} & \multicolumn{2}{|c|}{ II } & \multicolumn{2}{|c|}{ III } \\
\hline & & 1990 & 2020 & 1990 & 2020 & 1990 & 2020 \\
\hline POPULATION & 32.3 & 75.7 & 134.0 & 75.4 & 141.0 & 75.4 & 141.0 \\
\hline HAAVESTED ACAES & 8.5 & 9.4 & 9.8 & 8.5 & 8.5 & 8.5 & 8.5 \\
\hline UABAN DEPLETIONS AFMR & 2.3 & 5.3 & 10.1 & 5.3 & 10.6 & 5.3 & 10.6 \\
\hline STEAM ELECTRIC DEPLETIONS AF/YR & 0 & 14.7 & 37.3 & 12.8 & 24.0 & 12.8 & 24.0 \\
\hline MINERAL DEPLETIONS AF/YA & 1.0 & 2.0 & 3.0 & 2.0 & 3.0 & 2.0 & 3.0 \\
\hline AGRICULTURAL DEPL AFMR & 14.0 & 15.5 & 16.2 & 140 & 14.0 & 14.0 & 14.0 \\
\hline TOTAL WATEA DEPL AFMA & 17 & 37 & 67 & 34 & 52 & 34 & 52 \\
\hline DEPENDABLE WATER AF/YR' & 17 & 37 & 67 & 34 & 52 & 34 & 52 \\
\hline SURPLUS SUPPLY (Det.)* & 0 & 0 & 0 & 0 & 0 & 0 & 0 \\
\hline
\end{tabular}

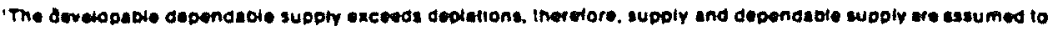
be in beince.

tOmicieneies may exist in locilized wess.

Figure 17: Projected Alternatives for Water Use in Apache County. Source: Arizona Water Comission (1977) 


\section{PROJECTED ALTERNATIVE WATER DEPLETIONS AND DEPENDABLE SUPPLY}

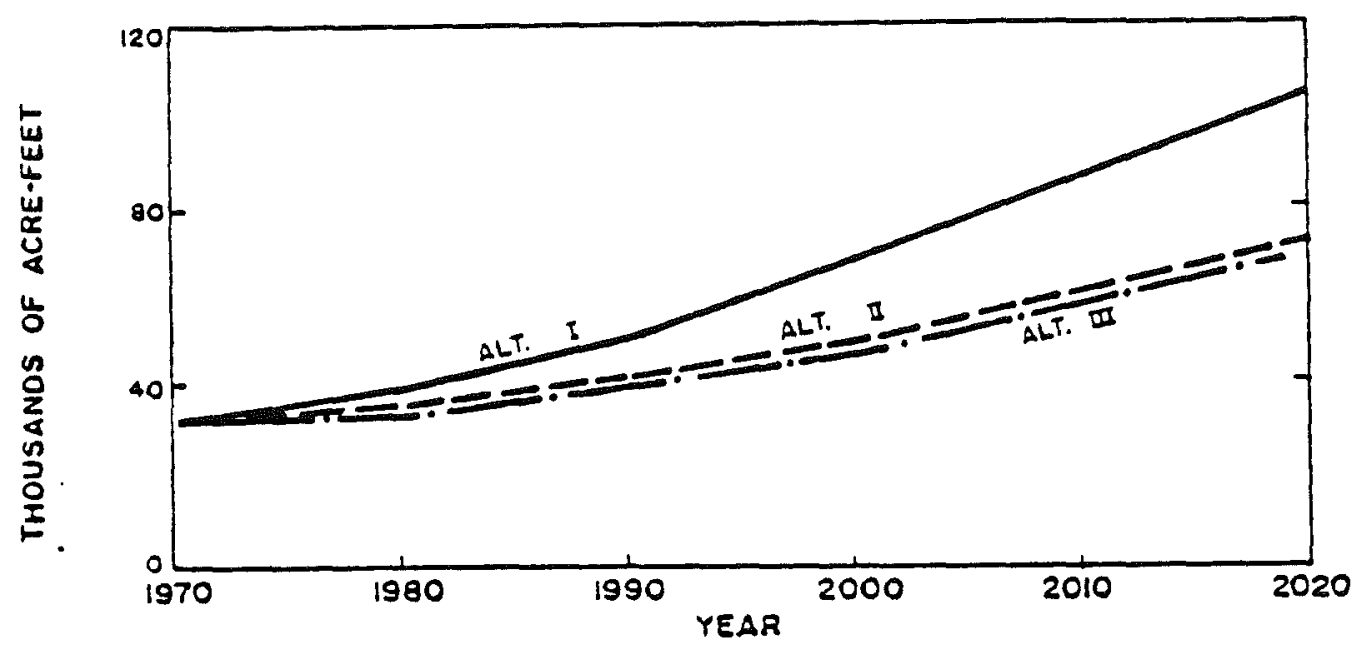

\section{ALTERNATIVE FUTURES SUMMARY}

\begin{tabular}{|c|c|c|c|c|c|c|c|}
\hline \multirow{3}{*}{$\begin{array}{c}\text { ITEM } \\
\text { (Ouentites in Thousands) }\end{array}$} & \multirow[b]{3}{*}{1970} & \multicolumn{3}{|c|}{ ALTERNATIVE } & \multicolumn{3}{|c|}{ FUTURES } \\
\hline & & \multicolumn{2}{|c|}{1} & \multicolumn{2}{|c|}{$\|$} & \multicolumn{2}{|c|}{ Iii } \\
\hline & & 1990 & 2020 & 1990 & 2020 & 1990 & 2020 \\
\hline POPULATION & 38.8 & 108.0 & 191.0 & 670 & 92.8 & 67.0 & 92.8 \\
\hline HARVESTED ACAES & 8.0 & 6.7 & 6.9 & 6.0 & 6.0 & 6.0 & 6.0 \\
\hline URBAN DEPLETIONS AF/YR & 4.9 & 8.8 & 15.8 & 5.4 & 7.6 & 5.4 & 7.6 \\
\hline STEAM ELECTAIC OEPLETIONS AF/YA & 0 & 0 & 22.7 & 0 & 9.5 & 0 & 9.5 \\
\hline MINEAAL OEPLETIONS AF/YR & 5.0 & 20.0 & 48.0 & 170 & 38.0 & 17.0 & 38.0 \\
\hline AGRICULTURAL OEPL AF/YA & 240 & 24.2 & 22.8 & 21.8 & 19.8 & 22.0 & 20.0 \\
\hline TOTAL WATEA DEPL. AF/YA & 34 & 53 & 109 & $\$ 4$ & 75 & 44 & 75 \\
\hline DEPENOABLE WATER AF/YA' & 22 & 46 & 58 & $\$ 1$ & 47 & 41 & 47 \\
\hline SURPLUS SUPPLY (DOP.) & (12) & (9) & (51) & (3) & (28) & (3) & (28) \\
\hline
\end{tabular}

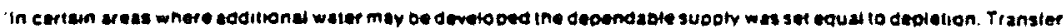
trom aless where a supply could be developed to deficient aress is not tessibie becsuse al geographic condition. ineretore. delticiencies are unarowade.

Figure 18: Projected Alternatives for Water Use in Yavapai County. Source: Arizona Water Comission (1977) 
PROJECTED ALTERNATIVE WATER DEPLETIONS

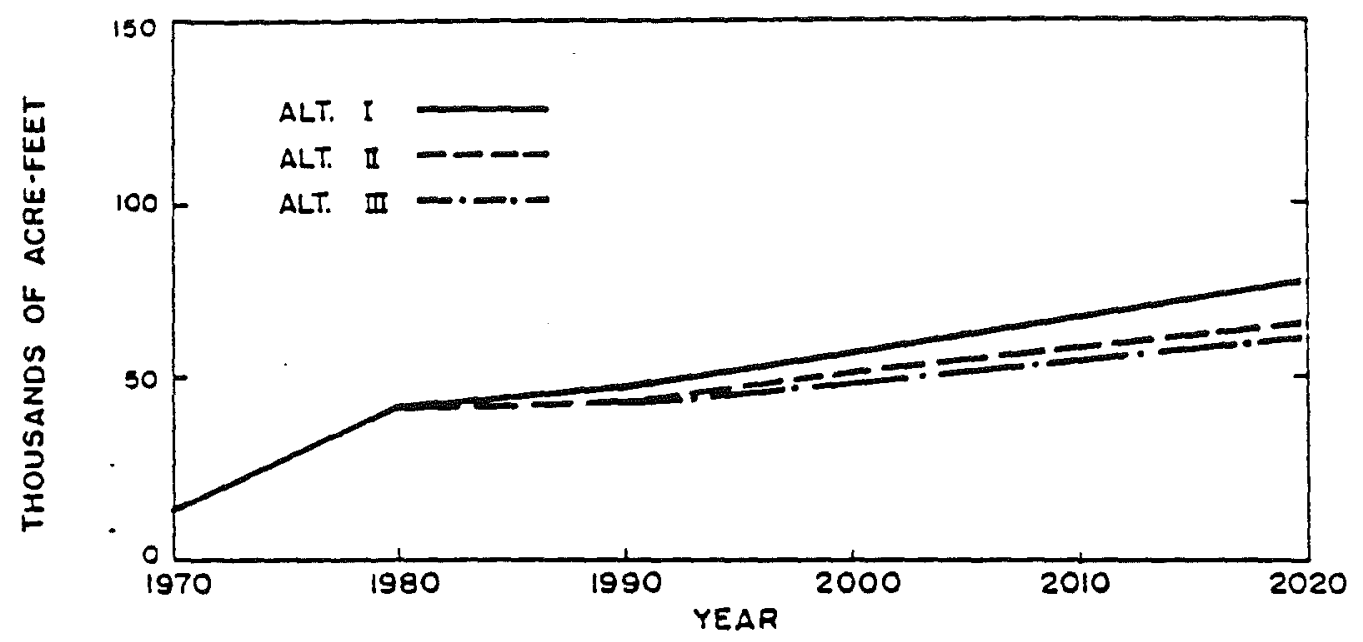

NOTE. Dependatie sudoly can be develoded to satisty depletiong in all timetrames

\section{ALTERNATIVE FUTURES SUMMARY}

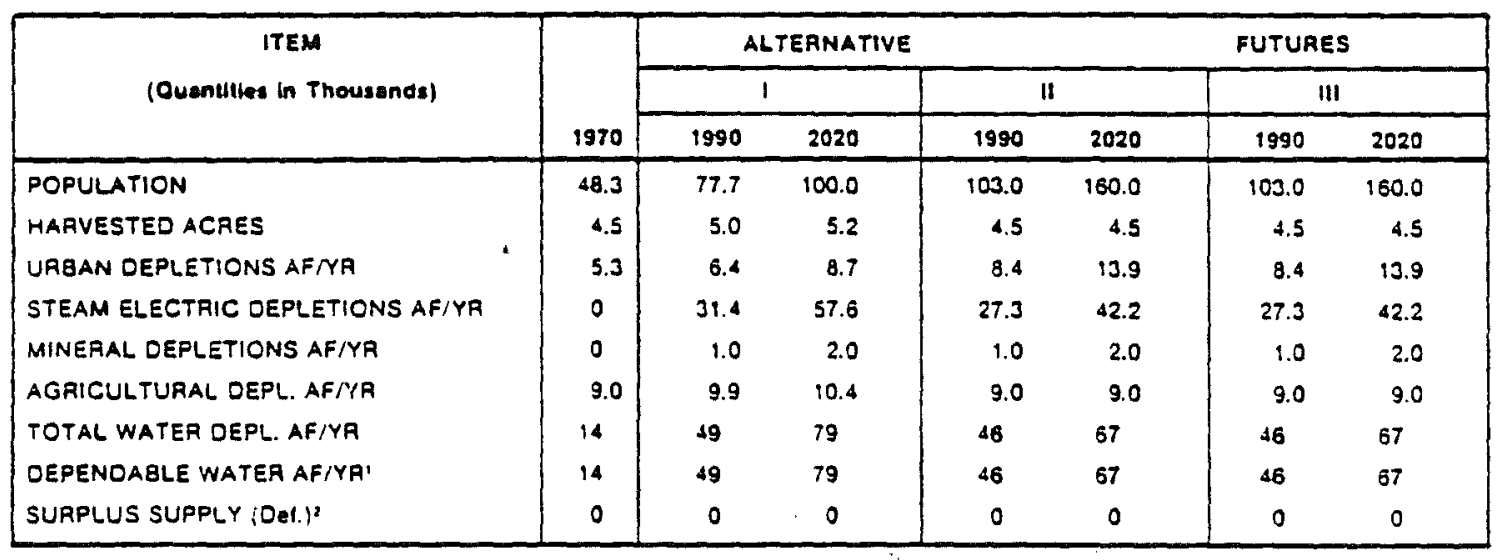

- The deverodable dependade sudoty excoess deptetions. therefore. supply and dependabie sudoly are assumed to De in Dalance.

:Deficieneres may exist in localized areat.

Figure 19: Projected Alternatives for Water Use in Coconino County. Source: Arizona Water Comission (1977) 
PROJECTED ALTERNATIVE wATER DEPLETIONS

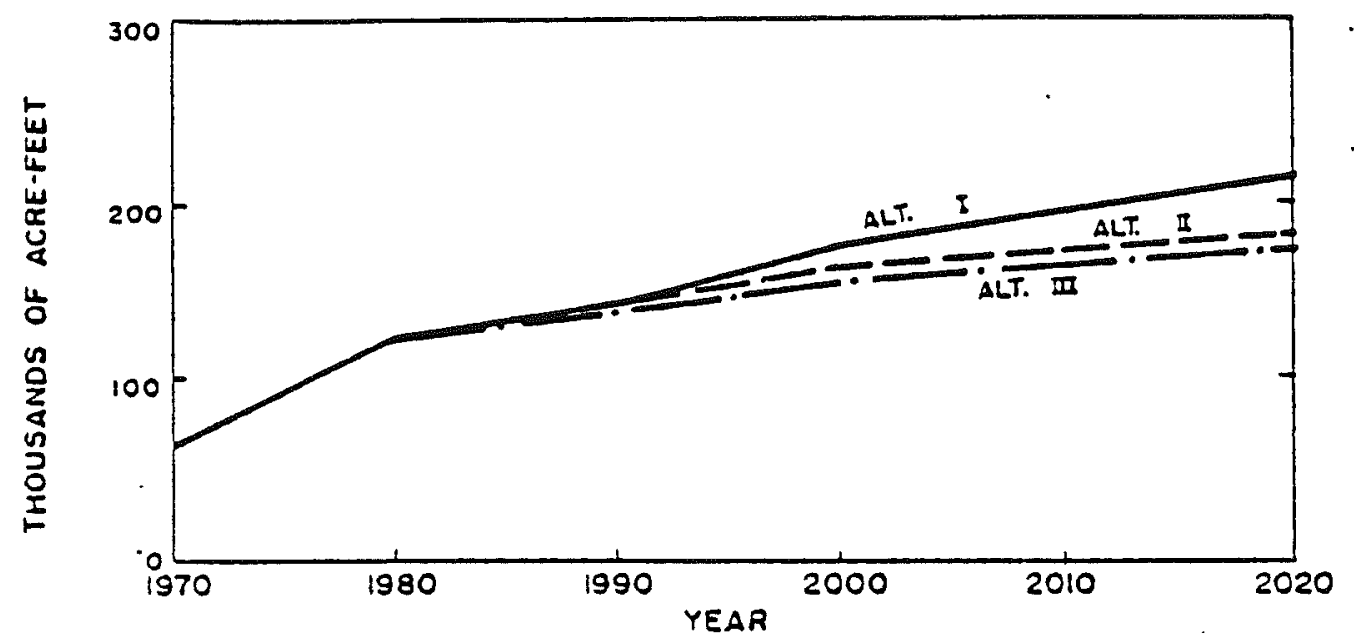

\section{ALTERNATIVE FUTURES SUMMARY}

\begin{tabular}{|c|c|c|c|c|c|c|c|}
\hline \multirow{3}{*}{$\begin{array}{c}\text { ITEM } \\
\text { (Ouantilios in Thousends) }\end{array}$} & \multirow[b]{3}{*}{1970} & \multicolumn{3}{|c|}{ ALTERNATIVE } & \multicolumn{3}{|c|}{ FUTURES } \\
\hline & & \multicolumn{2}{|c|}{1} & \multicolumn{2}{|c|}{11} & \multicolumn{2}{|c|}{ III } \\
\hline & & 1990 & 2020 & 1990 & 2020 & 1990 & 2020 \\
\hline POPULATION & 25.9 & 52.6 & 94.3 & 55.6 & 82.4 & 55.8 & 82.4 \\
\hline HAAVESTEO ACAES & 8.0 & 24.9 & 31.1 & 24.5 & 30.3 & 23.8 & 28.9 \\
\hline URBAN OEPLETIONS AF/YR & 6.7 & 9.0 & 15.7 & 9.5 & 13.9 & 9.5 & 13.9 \\
\hline STEAM ELECTAIC DEPLETIONS AFTY & 0 & 0 & 26.2 & 0 & 10.9 & 0 & 10.9 \\
\hline MINERAL DEPLETIONS AF/YA & 4.0 & 9.0 & 28.0 & 9.0 & 18.0 & 9.0 & 18.0 \\
\hline AGAICULTURAL OEPL. AF/YA & 23.0 & 97.0 & 112.0 & 94.7 & 109 & 92.0 . & 104.0 \\
\hline TOTAL WATEA DEPL. AF/YR' & 71 & 152 & 219 & 150 & 189 & 148 & 184 \\
\hline DEPENOABLE WATER AF/YAT & 67 & 138 & 187 & 139 & 169 & 139 & 169 \\
\hline SUAPLUS SUPPLY (OAT.) & (4) & (14) & (32) & (11) & $(20)$ & (9) & (15) \\
\hline
\end{tabular}

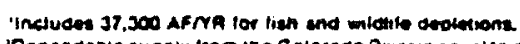

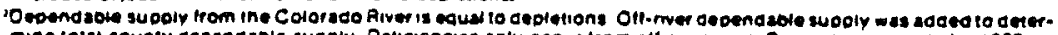

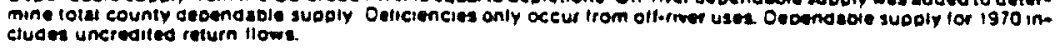

Figure 20: Projected Alternatives for Water Use in Mohave County. Source: Arizona Water Commission (1977) 
For Gila, Navajo, Apache and Yavapai counties, little change is expected in water use for irrigated agricultural production. Under Alternatives II and III, water use in Coconino County in the year 2020 is projected to be over double the current levels. In Mohave County, all three alternatives show water use for irrigated agricultural production at least tripling by 1990 and continuing to increase to the year 2020 .

Large increases are forecast in the amount of water used to cool steam electric power plants. Water use has increased significantly due to the construction of new and the expansion of existing power plants. Additional coal-fired plants and plant expansion are anticipated so that by 2020 , water use will range from 68,000 to 154,000 acre-feet per year. As much as 23,000 acre-feet of this may occur in Yavapai County if the high projection of electrical power generation in Arizona is realized.

Both Yavapai and Mohave counties anticipate major expansions of the existing copper mines. Although water used for this purpose will increase with the projected increase in mineral production, it will continue to be less than 10 percent of the statewide levels.

Several surface water hydrologic areas supply water to northern Arizona. The Colorado River Drainage Basin supplies water to most of the developed areas in Apache, Coconino and Navajo counties. The Verde River Basin supplies water to urban development in Yavapai County. The Colorado River supplies Mohave County with water. Future dependable supplies along the Colorado River are projected to equal depletions. However, off-river uses of water will result in deficiencies for Mohave County under all three alternatives. 


\section{DISTRICT HEATING}

Both Springerville and Alpine, located in the White Mountains of east-central Arizona, experience severe winters. Evidence for geothermal potential in the area suggests that geothermal district heating systems for the two towns may be feasible.

\section{Alpine}

The community of Alpine is a small town located in the White Mountains of east-central Arizona approximately 25 miles south of Springerville, Arizona. The community has a population of 500 people and has historically experienced very slow growth. Future growth is expected to be only one percent per year during the next 20 years. Because the community is isolated, utility services are not available. Most people heat their homes with purchased diesel oil or propane. In addition, the mountain location results in severe winters of much longer duration than is the case in southern Arizona. For comparison, heating degree days for Alpine are 7500 versus 1500 in Phoenix. These circumstances make Alpine a possible candidate for a geothermal heating system.

Preliminary studies on the potential existence of geothermal energy resources in the Alpine and Springerville area have been completed by the Arizona Bureau of Geology and Mineral Technology, Geothermal Group. Although the conclusions of the study are far from definitive, several comments are worth noting. First, the study concludes that "a relatively shallow heat source of unknown character and dimension exists, probably beneath the area between Springerville and Alpine. Second, groundwater supplying the eastern half of the area is positively affected by this heat source." In addition to these conclusions, a shallow bore hole has been drilled just north of Alpine. The hole had a temperature of $33^{\circ} \mathrm{C}\left(91^{\circ} \mathrm{F}\right)$ at a 
depth of $357 \mathrm{~m}(1170 \mathrm{ft})$. The estimated temperature gradient was $75^{\circ} \mathrm{C} / \mathrm{km}$ $\left(5^{\circ} \mathrm{F} / 100 \mathrm{ft}\right)$. The economic analysis which follows assumes the existence of a geothermal resource with the above characteristics.

The following analysis concerns the economic factors necessary to develop a geothermal heating district in Alpine. Two cases are considered. The first case assumes that the City of Alpine establishes a local public service company responsible for the development, distribution and management of the heating district. The intent of the utility would be to provide hot water for domestic and commercial space heating and hot water needs while earning a modest profit. The second case assumes that a private (investor-owned) utility would be responsible for development, distribution and management of the district heating system. The intent of the utility would be to earn a profit on its operations. Both options are consilered feasible methods for geothermal development.

The geothermal heating district for Alpine would consist of 167 residential houses as well as commercial buildings. It is assumed that commercial heat demand is equal to residential heat demand. Estimated residential peak demand for the commity is 7,516,000 Btu/hr. The developer would be required to drill wells necessary for the system. It is assumed that $60^{\circ} \mathrm{C}\left(140^{\circ} \mathrm{F}\right)$ geothermal water could be discovered at $914 \mathrm{~m}$ (3000 ft) at a distance of one mile from Alpine. It is further assumed that the flow rate would be $1890 \mathrm{l} / \mathrm{min}$ (500 gpm). Lastly, people living in Alpine must purchase fuel oil or propane for use in heating houses and businesses. It is assumed that the price of purchased energy is $\$ 7.00 / \mathrm{MB}$ tu. Table 7 presents a summary of assumptions for the two cases considered. 


\begin{tabular}{lcc}
\hline Variable & $\begin{array}{c}\text { City } \\
\text { Development }\end{array}$ & $\begin{array}{c}\text { Private } \\
\text { Development }\end{array}$ \\
\hline Resource Temperature & $60^{\circ} \mathrm{C}\left(140^{\circ} \mathrm{F}\right)$ & $60^{\circ} \mathrm{C}\left(140^{\circ} \mathrm{F}\right)$ \\
Depth & $914 \mathrm{~m}(3000 \mathrm{ft})$ & $914 \mathrm{~m}(3000 \mathrm{ft})$ \\
Flow Rate & $18901 / \mathrm{min}(500 \mathrm{gpm})$ & $18901 / \mathrm{min}(500 \mathrm{gpm})$ \\
Distance & $1609 \mathrm{~m}(1 \mathrm{mile})$ & 1609 m (1 mile) \\
Bond rate (above inflation) & $1 \%$ & $2 \%$ \\
Equity Capital & $10 \%$ & $10 \%$ \\
Sales Tax Rate & $0 \%$ & $5 \%$ \\
State Tax Rate & $0 \%$ & $15 \%$ \\
Federal Tax Rate & $0 \%$ & $46 \%$ \\
Geothermal Tax Credit & $0 \%$ & $15 \%$ \\
Minimum Tax Rate & $0 \%$ & $15 \%$ \\
Property Tax Rate & $0 \%$ & $1 \%$ \\
Regular Investment Tax Credit & $0 \%$ & $10 \%$ \\
Required Rate of Return & $1 \%$ & $20 \%$ \\
$\quad$ (above inflation) & & $\$ 1.00$ \\
Conventional Fuel Price (MBtu) & $\$ 7.00$ & $2 \%$ \\
Real Fuel Price Growth & $2 \%$ & 20 \\
$\quad$ (per year) & 20 & \\
Project Life (years) & & \\
\hline
\end{tabular}

Using the above-outlined assumptions, a life-cycle cost for geothermal energy was calculated and compared to the price of propane. The price of geothermal energy was found to be $\$ 4.55$ under private development and $\$ 4.33$ under city development. In both cases, geothermal energy can be supplied at a price less than the price of currently available fuel. Net fuel cost savings over the life of the project total $\$ 3,693,000$ under city development and $\$ 2,795,000$ under frivate development. Table 8 presents an itemized cost summary for the two cases considered. 
TABLE 8: COST SUMMARY FOR ALPINE DISTRICT HEATING SYSTEM

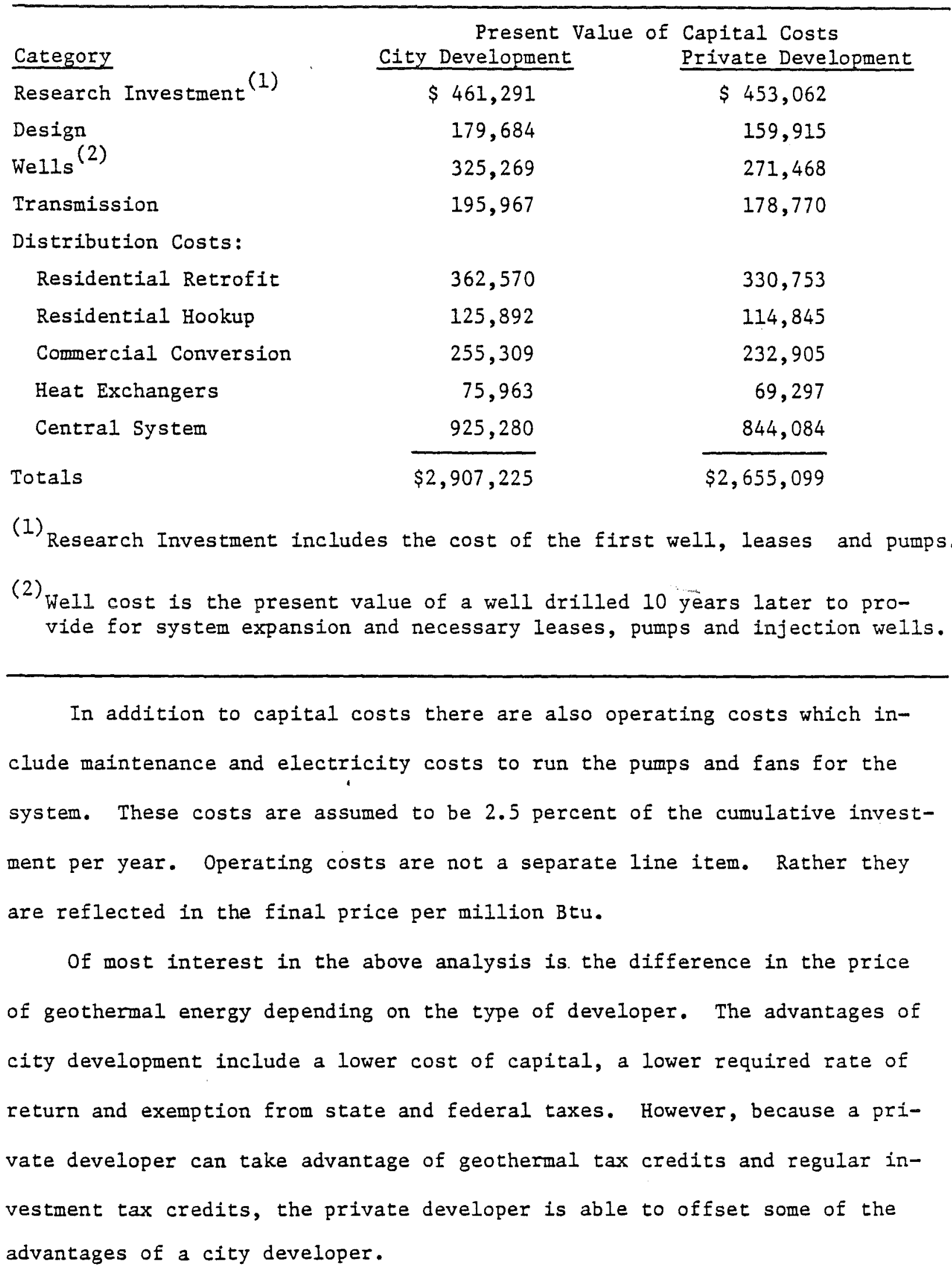




\section{Springerville}

Springerville, Arizona, along with the adjacent community of Eagar, is located about 220 miles northeast of Phoenix in the White Mountains of Apache County. Historically, Springerville has been an agricultural com- . munity relying heavily on cattle and sheep grazing. Today, the largest employment sector is the lumber industry followed by the construction industry. Currently, two large coal-fired power plants are under construction in the area. The population of the Springerville area is estimated to be 5,600 people and the annual compound growth rate during the past 10 years was 5.8 percent. Future population projections suggest a growth rate of 4.2 percent per year over the next 20 years. As was the case with Alpine, Springerville experiences long winters and very mild summers. Heating degree days exceed 6000 for the Springerville area, making it a good candidate for district heating using geothermal energy.

The economic analysis which follows assumes the existence of a geothermal resource. As was the case with the Alpine analysis, only preliminary studies on the local gethermal resource potential have been performed. The reader should refer back to the Alpine section for resource information.

In this analysis, the economics of a geothermal district heating system are compared for two cases. The first case assumes that the district heating system is established for existing residential and comercial buildings. The second case assumes that a new subdevelopment would be constructed with the intention of using geothermal energy to provide space heating and hot water. In both cases it is assumed that a city utility develops the district heating system. It is also assumed that current energy users consume electricity for their space heat and hot water needs. 
For both cases, the geothermal district heating system would consist of 250 residential houses as well as commercial buildings. It is assumed that total comercial demand is equal to 10 percent of residential demand. Estimated total peak demand for the system is calculated to be $10,518,750 \mathrm{Btu} / \mathrm{hr}$. It is assumed that $60^{\circ} \mathrm{C}\left(140^{\circ} \mathrm{F}\right)$ geothermal water could be discovered at $914 \mathrm{~m}(3000 \mathrm{ft})$ at a distance of one mile from the site. It is further assumed that the flow rate would be $37801 /$ min (1000 gpm). Table 9 presents a sumary of assumptions for the analysis.

TABLE 9: ASSUMPTIONS FOR SPRINGERVILIE DISTRICT HEATING SYSTEM

Variable

Resource Temperature

Depth

Flow Rate

Distance

Bond Rate (above inflation)

Equity Capital

Taxes (Federal and State)

Tax Credits

Population

Rate of Return (above inflation)

Price of Conventional Fuel (per MBtu)

Project Life (years)

Assumed Value
$60^{\circ} \mathrm{C}\left(140^{\circ} \mathrm{F}\right)$
$914 \mathrm{~m}(3000 \mathrm{ft})$
$37801 / \mathrm{min}(1000 \mathrm{gpm})$
$1690 \mathrm{~m}(1 \mathrm{mile})$
$1 \%$
$10 \%$
0
0
750
$1 \%$
$\$ 10$
20

Under the above assumptions, two life-cycle costs for geothermal energy were calculated. If the development of a geothermal district heating system Involved retrofitting existing homes and comercial buildings, the life-cycle price of geothermal energy was calculated to be $\$ 5.53$ per million Btu. This price includes the costs for hookup and conversion of each structure to be heated. If a new development were built and designed to use geothermal 
heat, the price of geothermal energy would be $\$ 3.96$ per willion Btu. In addition, each home would require $\$ 1,250$ worth of hookup and heating equipment. In both cases, the geothermal price compares quite favorably with local costs for both electricity and propane. In the retrofit case, total fuel cost savings over 20 years would equal $\$ 2,618,000$; in the new growth case, total fuel cost savings would equal $\$ 3,538,000$. Table 10 presents an itemized cost sumary for the two cases considered.

TABLE 10: COST SUMMARY FOR SPRINGERVILLE DISTRICT HEATING SYSTEM

\begin{tabular}{lcc}
\hline & \multicolumn{2}{c}{ Present Value of Capital Costs } \\
Category & Retrofit Case & New Growth Case \\
\cline { 2 - 3 } Design & $\$ 238,011$ & $\$ 168,810$ \\
Wells & 515,983 & 515,983 \\
Transmission & 146,707 & 146,707 \\
Distribution: & & 0 \\
Residential Retrofit & 466,917 & 0 \\
Residential Hookup & 162,124 & 0 \\
Commercial Conversion & 32,879 & 47,158 \\
Heat Exchangers & 47,158 & 935,924 \\
Central System & 935,924 & $\frac{1,814,582}{\text { Totals }}$ \\
\cline { 2 - 3 } & $\$ 2,545,701$ &
\end{tabular}

*Well cost includes production wells, injection wells, pumps and lease costs.

In addition to the capital costs are operating costs which are estimated to be 2.5 percent of the total cumulative investment in each year. These costs are reflected in the total price of the energy.

It is obvious from the above analysis that new growth situations are preferable to retrofit situations for establishing geothermal district heating systems. However, in the new growth situation, energy users must pay for the equipment installed in each home. The effect would be to increase the 
price of each home or comercial building although the price of the heating equipment is comparable to prices for current furnace units. A second point worth noting is that the system analyzed contains significant excess capacity. Expansion of the heating district to 750 homes would be possible without incurring additional drilling costs. MATCHING GEOTHERMAL RESOURCES TO POTENTIAL USERS

In order to define a time frame in which geothermal energy will realize comercial use, projections were made of the amount of geothermal energy on line as a function of time. It was with the assistance of the New Mexico Energy Institute (NMEI) that this time line was produced. For modeling purposes, it was assumed that geothermal energy comes on line when its price becomes lower than that of energy alternatives. Projections of geothermal energy on line for industrial process heat under private development and city-owned utility development are presented in Figure 21 and Figure 22, respectively. Projections of geothermal energy on line for the residential, commercial and industrial sectors under private development and city-owned utility development are presented in Figure 23 and Figure 24, respectively.

The figures show that city-owned utility development of a resource occurs sooner than does private development. For example, Figure 21 indicates that under private development geothermal energy for industrial process heat would come on line by 1989 and would rise rapidly to 2020 as prices of other forms of energy increase. Figure 22 shows that geothermal energy for industrial process heat would come on line even sooner (1983) under city-owned utility development with the amount on line rising rapidly to 2005 . The major reasons for a resource being 


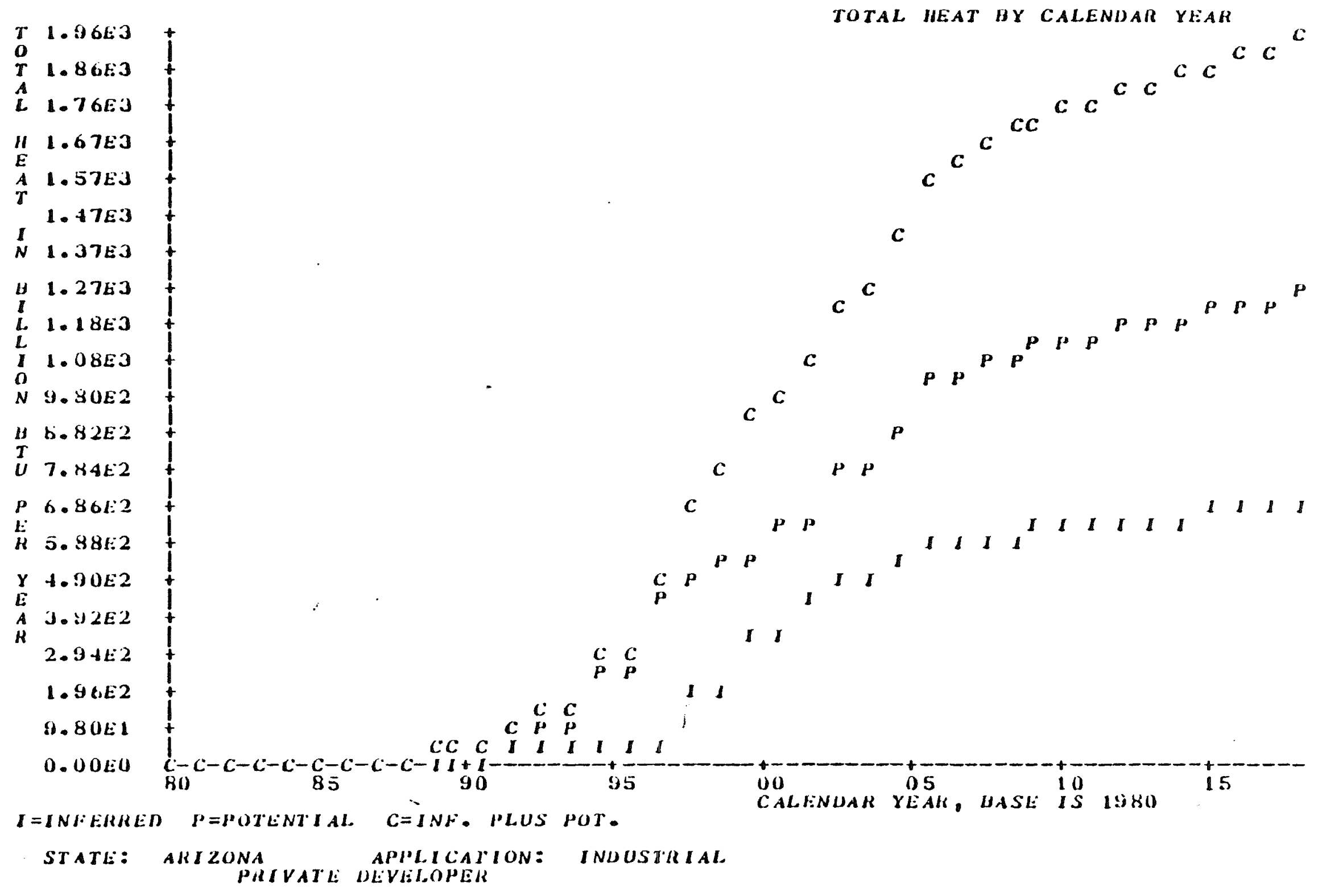

Figure 21: Profected Geothermal Heat On Line Under Private Development. Source: New Mexico Energy Institute 


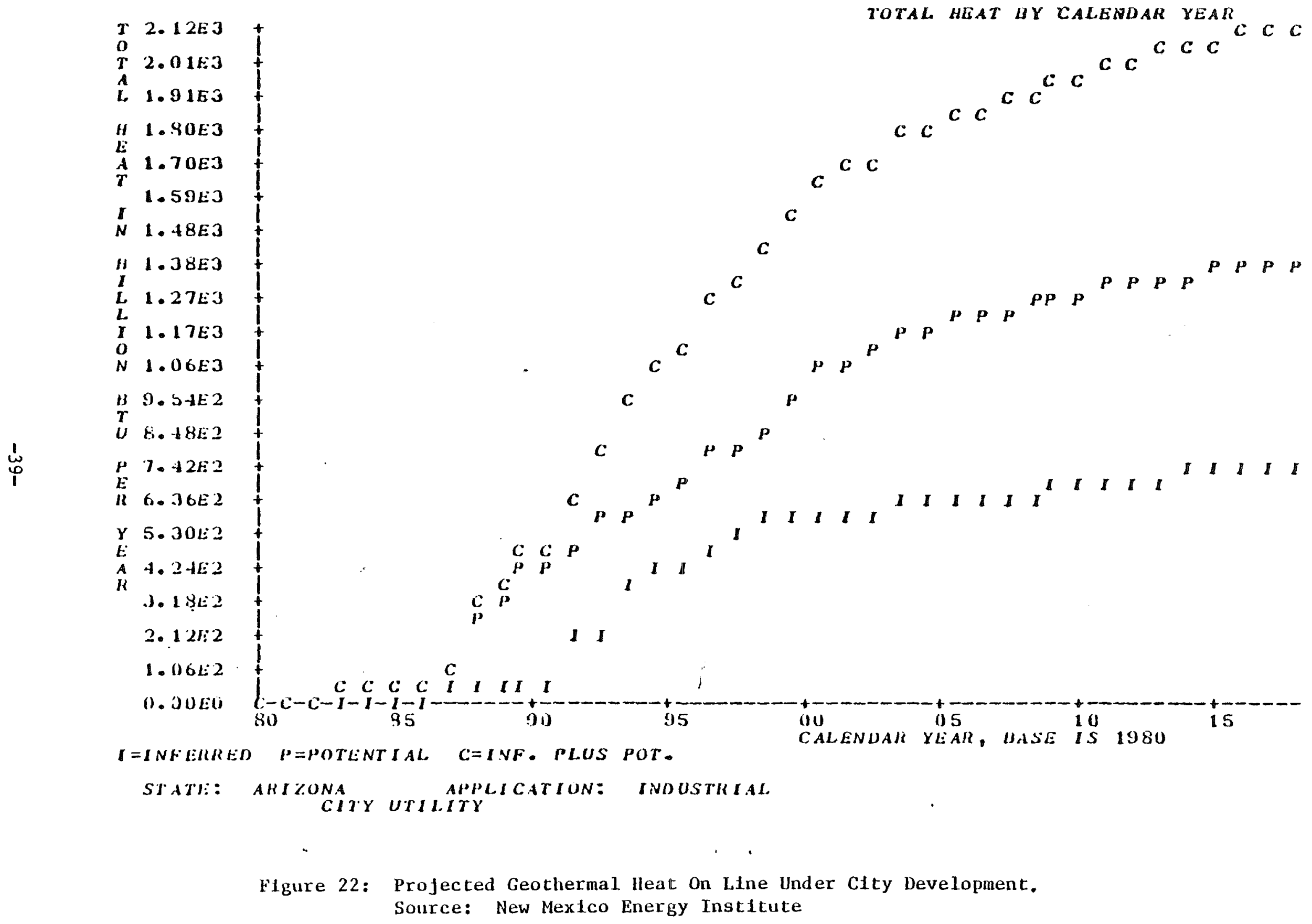




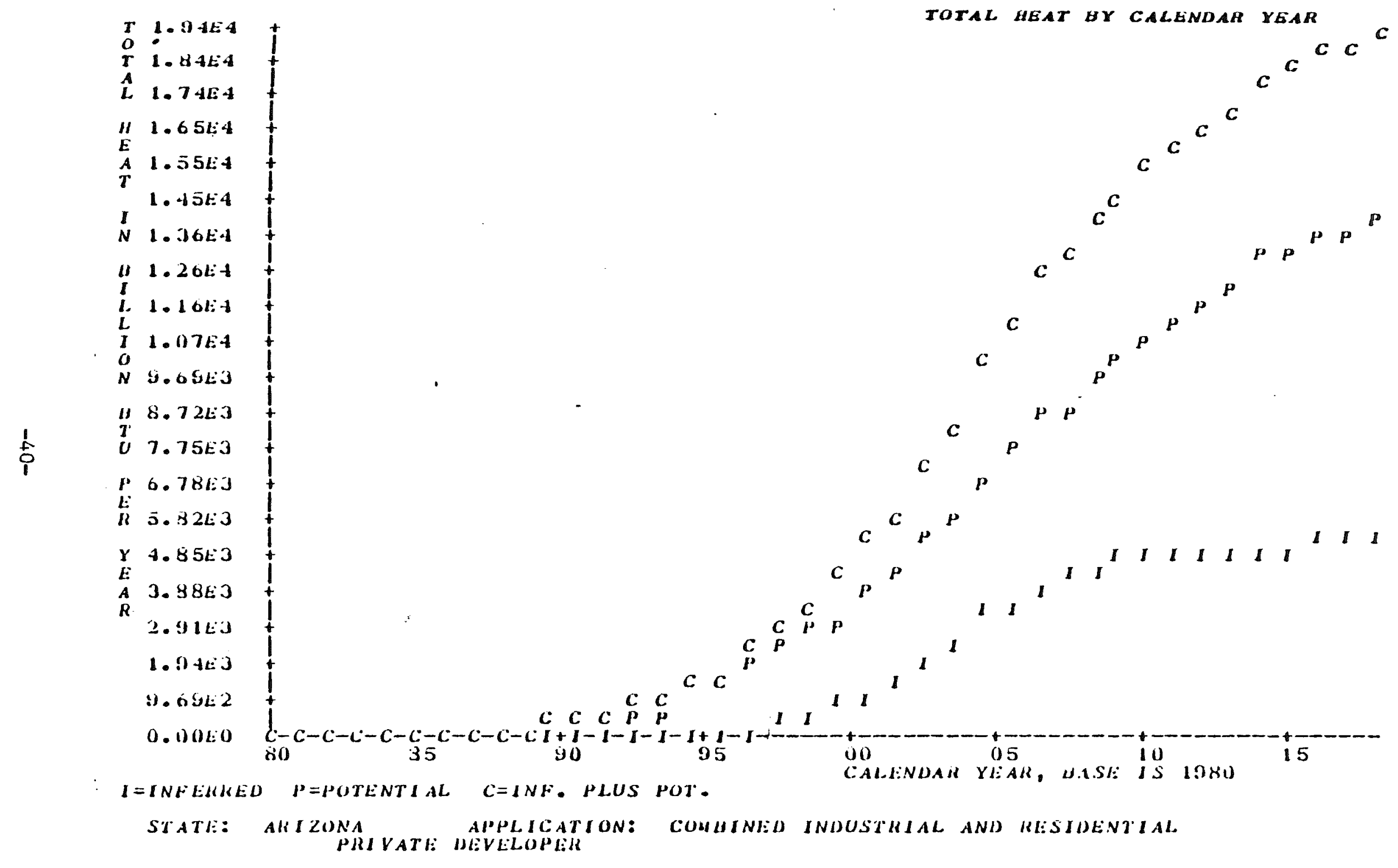

Fipure 23: Projected Geothermal Heat on Line Under Private Development for the Residential, Commerclal and Industrial Sectors.

Source: New Hexico Energy Institute 


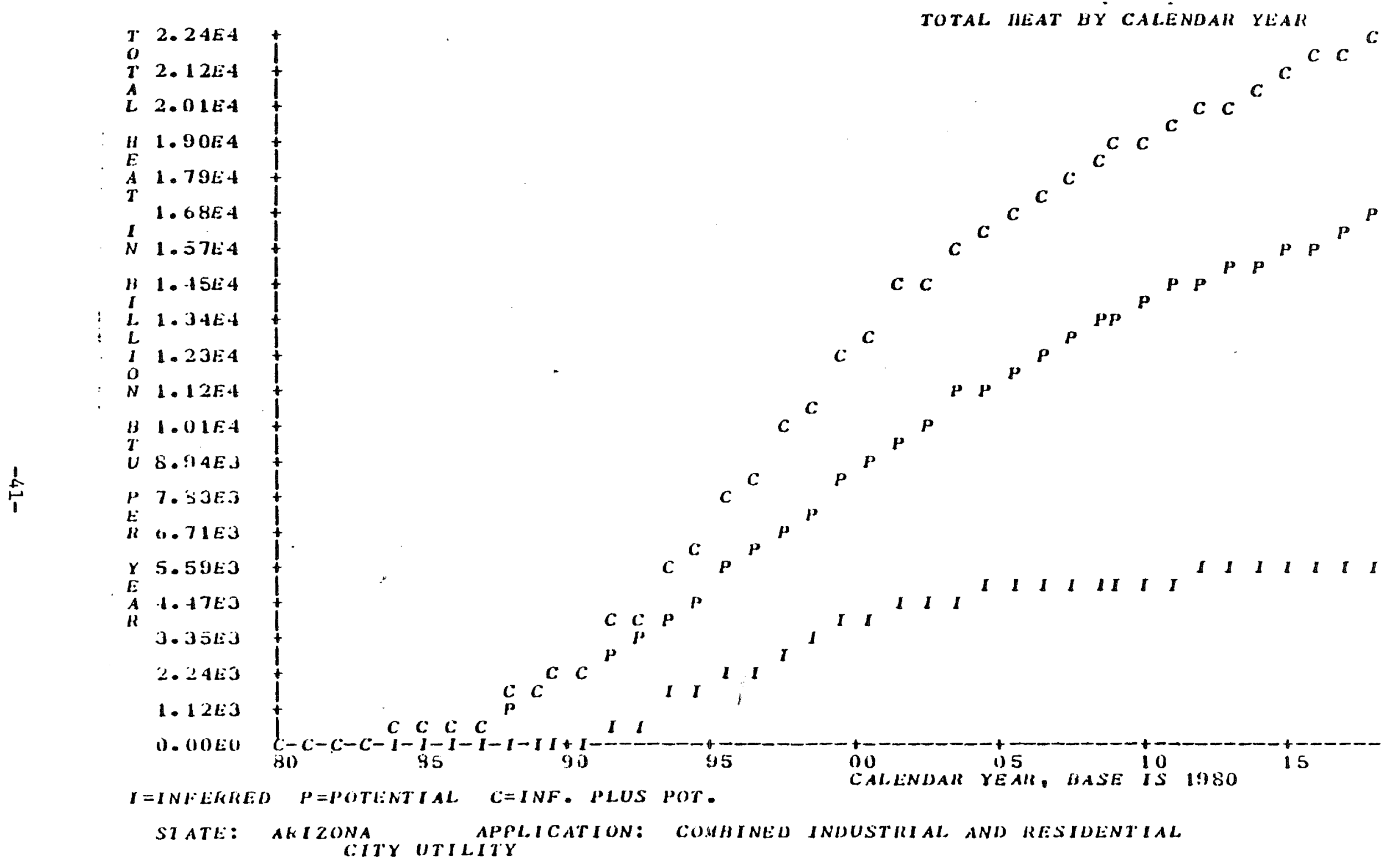

Figure 24: Projected Geothermal Heat On Line Under City Development for the Residential, Conmercial and Industrial Sectors. Source: New Mexico Energy Institute 
developed more quickly by a city-owned utility than by a private investor are that a city typically has lower capital costs than private industry and a city utility requires a lower rate of return on invested capital. For comparative purposes, Table 11 reports energy on line in terms of barrels of oil replaced annually by geothermal energy.

TABLE 11: BARRELS OF OIL REPLACED BY GEOTHERMAL ENERGY Industrial Process Heat Market

\begin{tabular}{|c|c|c|c|c|}
\hline & 1985 & 1990 & 2000 & 2020 \\
\hline Private Developer & 0 & 9357 & 165,000 & 350,000 \\
\hline City Utility & 9482 & 87,500 & 276,796 & 378,571 \\
\hline
\end{tabular}

Similarly, Figures 23 and 24 show that geothermal energy for the residential, comercial and industrial sectors (the residential and comercial sectors are combined) comes on line more quickly under city-owned utility development than under private development. Under city development, geothermal energy would come on line in 1983 while under private development, geothermal energy would not come on line until 1989. Table 12 reports energy on line in terms of barrels of oil replaced annually by geothermal energy.

TABLE 12: BARRELS OF OIL REPLACED BY GEOTHERMAL ENERGY Residential, Commercial and Industrial Markets

\begin{tabular}{|c|c|c|c|c|}
\hline & 1985 & 1990 & 2000 & 2020 \\
\hline Private Developer & 0 & 64,821 & 253,571 & $3,464,285$ \\
\hline City Utility & 66,785 & 417,857 & $2,196,429$ & $4,000,000$ \\
\hline
\end{tabular}


Further details of the NMEI model for projecting geothermal energy on line are given in Appendix A.

Facilities serving a large number of people are potential users of geothermal energy. In northern Arizona these facilities include high schools, community colleges or universities and airports located in Holbrook, Winslow, Prescott and Flagstaff. Also, several industries located in or near the major cities of the northern counties may be able to use geothermal energy for both their space heating and process heat needs. In Winslow, the Wometco Coca-Cola Bottling Co. of Northern Arizona is a potential user of geothermal energy; Ramsey Logging and Timber Co., located 40 miles south of Winslow, is another potential user. Potential users in Prescott include Aquarium Pump Supply, Quality Plastics of Prescott, U.S. Electrical Motors and Morris Maler Shirt Manufacturing Co. In Kingman, industries which might benefit from the use of geothermal energy include General Cable Co. and Tucker Housewares.

Potential users in Flagstaff include E-Z Mills, Jeld-Wen, Incorporated of Arizona, Ponderosa Paper Products, Ralston Purina Company, Southwest Forest Industries and Spring City Knitting Co. Geothermal applications may also exist for the Snowflake Division of Southwest Forest Industries. The ready-mix concrete and tine sawmill industries of northern Arizona may be able to use geothermal energy for their process heat needs. Potential geothermal applications to processess within these industries, identified by a four-digit Standard Industrial Classification (SIC) code, are discussed below. Estimates of annual energy consumption as well as the process temperatures required by these industries were provided by the Solar Energy Research Institute. Information on the specific heat 
temperatures needed in each of the operations within these industries was gathered from three principal sources: the Noyes Data Corporation publ1cation entitled "Energy-Saving Techniques for the Food Industry;" Drexel University's Energy Analysis of 108 Industrial Processes, Phase I of an Industrial Applications Study, 1979; and a Survey and Analysis of Solar Energy Process Heating Opportunities in Arizona prepared by the University of Arizona.

Ready-Mix Concrete Industry (SIC 3273)

There are seven large firms within this industry, most of which are located in Mohave County. The principal characteristic of the ready-mix concrete industry is that the concrete is poured wet and is allowed to set at ambient temperature. Therefore, little of the energy consumed by this industry is for process heat. Electricity is used in the crushing and mixing processes while fuel is used for transportation and mixing in transit. However, the industry does require large amounts of hot water for cleaning, mixing and storing. Geothermal energy possibly could be used to heat the water.

\section{Sawmills Industry (SIC 2421)}

There are four large mills within this industry located in northern Arizona, principally in Apache and Coconino counties. The process heat temperatures required by this industry never exceed $82^{\circ} \mathrm{C}$ ( $180^{\circ} \mathrm{F}$ ) with most of the processes requiring a temperature of $25^{\circ} \mathrm{C}\left(77^{\circ} \mathrm{F}\right)$. Therefore, the assessed geothermal reservoir temperatures of $50^{\circ} \mathrm{C}\left(122^{\circ} \mathrm{F}\right)$ for Coconino County and $95^{\circ} \mathrm{C}\left(203^{\circ} \mathrm{F}\right)$ for Apache County are sufficient for most of the processes within the industry.

Electricity, the dominant energy source in the industry, is used in 
almost all of the processes. Some of this electricity could be displaced if geothermal energy were used in the washing of logs, bolts and carts $\left(25^{\circ} \mathrm{C}\right.$ temperature requirement), in operating the drying kiln $\left(25^{\circ} \mathrm{C}\right.$ temperature requirement) and for space heating.

The results presented in this section suggest that northern Arizona could experience significant geothermal development; however, additional factors may play a significant role to improve the potential for geothermal development. Northern Arizona has good potential for a substantial increase in residential and industrial development and is seeking to diversify its economy away from its traditional rural base. As additional industries and people are attracted to northern Arizona, greater development of its geothermal resource potential will become possible. Also, as additional resource assessment work is performed, greater resource potential may be discovered. Finally, northern Arizona could also benefit from geothermal space cooling as well as space heating, further adding to the use of geothermal energy resources. 


\section{Appendix A}

The New Mexico Energy Institute at New Mexico State University has developed a computer simulation model, BTHERM, to assess the economic feasibilfty of residential and commercial district space heating, hot water heating and industrial process heating uslag low temperature geothermal energy. Another model, CASH, was developed to depict the growth of geothermal energy on line over the next 40 years as a function of price of competing energy sources. A major assumption of these models is that geothermal energy must be price-competitive with the lowest-cost conventional energy source in order to assure market capture.

Development of a geothermal resource is characterized by large capital outlays, but a long-term geothermal investment has the potential to provide relatively inexpensive energy at a stable price. Unlike natural gas and electricity, however, geothermal energy is an unknown energy involving certain risks such as price and reservoir life and the need for back-up systems. An analysis of the costs and economic competitiveness of geothermal energy must take these uncertainties into account. Thus, costs may be overestimated so that the benefits will not be overstated. BTHERM models the residential, commercial and industrial sectors of a typical city, each sector having unique energy costs and energy system physical parameters as well as different growth rates. The model possesses the ability to model each sector individually and can analyze the application of geothermal energy to new growth only, to conversion of existing structures or to a combination of both. The model also has the capability to model both private and city-owned utility development of the geothermal resource. 
Output of the model includes the levelized price per million Btu of delivered energy, the discounted present value of investment necessary and the undiscounted values of investments for policy studies. Also, from input of the price and price growth rate of conventional energy, the model determines the discounted or undiscounted values for federal and state taxes, tax credits, royalty rates, property taxes and consumer savings due to conversion from conventional energy to geothermal. Certain limitations of the model have already been suggested. Costs, for example, may be overestimated due to safeguards built into the model to take into account the risks associated with geothermal energy. This overestimation of costs might result in the exclusion of a potential use of geothermal energy. Another limitation is that the price of natural gas is taken as the price of competitive (conventional) energy, but not all users have access to natural gas.

The output of the model is not a substitute for detailed engineering design studies but it is useful for determining order-of-magnitude costs and potential benefits of geothermal energy development. 


\section{BIBLIOGRAPHY}

References used in preparing the Area Development Plans

Arizona Agricultural Statistics 1978, 1979: Phoenix, Arizona, Arizona Crop and Livestock Reporting Service, 68 p.

Artzona Communtty Profiles, 1981: Phoenix, Arizona, Research Program, Arizona Office of Economic Planning and Development.

Arizona Statistical Review, 1979: Phoenix, Arizona, Valley National Bank of Arfzona, $72 \mathrm{p}$.

Brown, R., 1978, Industrlal Process Beat Demand Balance: Golden, Colorado, Solar Energy Research Inst1tute, unpublished draft.

Climatograph of U.S. No. 81 Aflzona, 1978: Asheville, North Carolina, National Climate Center.

Durn, D. and Cox, D.C., 1979, Papers in Community Development No. 2 - SocioEconomic Indicators for Small Towns: Tucson, Arizona, Rural Information Center, $58 \mathrm{p}$.

Energy Analysis of 108 Industŕfal Processes, 1979: Philadelphia, Pennsylvania, Drexel Dniversity.

Energy-Saving Techniques for the Food Industry, 1977, M.E. Casper, editor: Park Ridge, New Jersey, Noyes Data Corporation, 657 p.

Frank, 甘.J., 1977, Arlzona Energy Inventory: 1977: University of Arlzona, Tucson, $100 \mathrm{p}$.

Gerber, L.A., Worden, M.A., and Dunn, D., 1980, Papers in Community Deve1opment No. 5 - Safford, Arizona: A Trade Area Analysis: Tucson, Arizona, Rural Information Center, 76 p.

Gibson, L.J., Worden, M.A., and Solot, M.S., 1979, Papers in Comnuity Development No. 1 - A Cltizen's Bandbook for Evaluating Community Impacts: Tucson, Arizona, Rural Information Center, 65 p.

Hodgson, M.I., 1978, Arizona Job Scene 1985: A Labor Market Information Publication of the Arizona Department of Economic Securfty, $133 \mathrm{p}$. 
Industrial Waste Heat Survey, 1978, Rocket Research Company.

Inside Phoenix 1979, 1979: Phoenix, Arizona, Phoenix Newspapers, Inc., 152 p.

Inside Phoenix 1981, 1981: Phoenix, Arizona, Phoenix Newspapers, Inc., 128 p.

1981 Directory of Arizona Manufacturers, 1981: Phoenix, Arizona, Phoenix Metropolitan Chamber of Commerce, 200 p.

Phase II - Arizona State Water Plan: Alternative Future, 1977: Phoenix, Arizona, Arizona Water Commission, $145 \mathrm{p}$.

Population, Employment and Income Projections for Arizona Counties 1977 2000, July 1978 \& 1979: Arizona Department of Economic Security.

Population Estimates of Arizona as of July 1, 1979: Phoenix, Arizona, Arizona Department of Economic Security Report No. 12, 66 p.

Statistical Report for Financial Analysis 1969 - 1979: Phoenix, Arizona, Arizona Public Service Company, 24 p.

Stone, C., 1980, Preliminary Assessment of the Geothermal Potential at the Papago Farms, Papago Indian Reservation, Arizona: State of Arizona Bureau of Geology and Mineral Technologg Open-File Report 80-6, 62 p.

Stone, C., 1981, A Preliminary Assessment of the Geothermal Resource Potential of the Yuma Area, Arizona: State of Arizona Bureau of Geology and Mineral Technology Open-File Report 81-4, 28 p.

Survey and Analysis of Solar Energy Process Heat Opportunities in Arizona, 1979: University of Arfzona, Department of Nuclear Energy, Energy Management and Policy Analysis Group, Final Report prepared for Arizona Solar Energy Research Commission under Office of Econowic Planning and Development Contract No. 458-78

Swanberg, C.A., Morgan;, P., Stoyer, C.H., and others, 1977, An Appraisal Study of the Geothermal Resources of Arizona and Adjacent Areas in New Mextco and Utah and Their Value for Desalination and other Uses: New Mexico Energy Institute Report No. 6, 76 p. 
Tucson Trends 1980, 1980: Tucson, Arizona, Valley National Bank of Arizona and Tucson Newspapers Inc., 88 p.

Witcher, J.C., 1979, Proven, Potential and Inferred Geothermal Resources of Arizona and Their Heat Contents: State of Arizona Bureau of Geology and Mineral Technology Open-File Report $-5,65 \mathrm{p}$.

Witcher, J.C., 1981, Geothermal Energy Potential of the Lower San Francisco River Region, Arizona: U.S. Geological Survey Open-File Report 81-7, $135 \mathrm{p}$. 